Aus der Poliklinik für Zahnärztliche Prothetik

(Prof. Dr. med. dent. R. Bürgers)

im Zentrum Zahn-, Mund- und Kieferheilkunde

der Medizinischen Fakultät der Universität Göttingen

\title{
Die Auswirkungen eines FABP5-Knockdowns in chondrogenen Progenitorzellen
}

\author{
INAUGURAL - DISSERTATION \\ zur Erlangung des Doktorgrades \\ der Medizinischen Fakultät der \\ Georg-August-Universität zu Göttingen
}

vorgelegt von

Dr. med. dent. Philipp Buderer

aus

Ludwigsburg

Göttingen 2016 
Dekan:

Referent/in:

Ko-Referent/in:

Drittreferent/in:

Tag der mündlichen Prüfung:
Prof. Dr. rer. nat. H. K. Kroemer

Prof. Dr. med. N. Miosge

Prof. Dr. med. H. Hahn

Prof. Dr. med. R. Dressel

15.06.2017 


\section{Inhaltsverzeichnis}

Abkürzungsverzeichnis $\quad$ VI

1 Einleitung 1

1.1 Gelenkknorpel 1

1.2 Osteoarthrose 4

1.2.1 Epidemiologie der Osteoarthrose 4

1.2.2 Ätiologie und Pathologie der Osteoarthrose 5

$\begin{array}{ll}\text { 1.2.3 Therapieansätze } & 7\end{array}$

1.3 Chondrogene Progenitorzellen 8

1.4 Regulation der Chondrogenese 10

1.5 Fatty Acid Binding Protein 5 12

1.6 Fragestellung und Ziele dieser Arbeit 16

2 Material und Methoden $\quad 17$

$\begin{array}{lll}2.1 & \text { Immunhistochemie } & 17\end{array}$

2.1.1 Immunhistochemische Darstellung von FABP5 im Knorpel 17

$\begin{array}{ll}\text { 2.1.2 Verwendetes Knorpelgewebe } & 17\end{array}$

$\begin{array}{lll}2.2 & \text { Zellkultur } & 19\end{array}$

$\begin{array}{ll}\text { 2.2.1 Herkunft der CPCs } & 19\end{array}$

$\begin{array}{ll}\text { 2.2.2 Kultivierung der CPCs } & 19\end{array}$

$\begin{array}{ll}\text { 2.2.3 Passagieren der CPCs } & 20\end{array}$

2.3 Knockdown von FABP5 mit siRNA 21

2.3.1 Allgemeines zur Methode 21 
2.3.2 Transfektion der CPCs mit der siRNA

2.4 Quantitative real-time Polymerase Chain Reaction

2.4.1 Allgemeines

2.4.2 mRNA-Isolierung aus primären Zellen

2.4.3 Umschreiben von mRNA in cDNA

2.4.4 qRT-PCR-Protokoll

2.4.5 Primerdesign

2.4.6 Gradienten-PCR

2.4.7 Verwendete Primer

2.4.8 Statistik

2.5 Western Blot

2.5.1 Allgemeines

2.5.2 Proteinprobenvorbereitung

2.5.3 Natriumdodecylsulfat-Polyacrylamidgelelektrophorese

2.5.4 Der Western Blot

2.5.5 Proteindetektion

2.5.6 Immunmarkierung

2.5.7 Verwendete Antikörper

2.5.8 Auswertung der Western Blots

2.5.9 Strippen der PVDF-Membran

3.1 Immunhistochemischer Nachweis von FABP5 
3.2 Knockdown von FABP5 in CPCs 38

3.3 Nachweis von SOX9 41

3.4 Nachweis von RUNX2 43

3.5 Nachweis von Kollagen-Typ 1

4 Diskussion $\quad 47$

4.1 Vorkommen von FABP5 in CPCs und Knorpelgewebe 47

4.2 Einfluss des FABP5-Knockdowns auf SOX9 und RUNX2 48

4.3 OA und Adipositas 51

4.4 FABP5 und TGF- $\beta \quad 52$

4.5 Fazit und Ausblick 53

5 Zusammenfassung $\quad 54$

6 Anhang $\quad 55$

6.1 Abbildungsverzeichnis 55

6.2 Tabellenverzeichnis 56

7 Literaturverzeichnis $\quad 57$ 


\section{Abkürzungsverzeichnis}

\begin{tabular}{|c|c|}
\hline AK & Antikörper \\
\hline ACT & autologe Chondrozytentransplantation \\
\hline AOT & autologe osteochondrale Transplantation \\
\hline APS & Ammoniumperoxodisulfat \\
\hline BMP & bone morphogenic protein \\
\hline BSA & bovine serum albumin \\
\hline $\mathrm{CBF}$ & core-binding factor \\
\hline CDNA & copy DNA \\
\hline DMEM & Dulbecco's Modified Eagle's Medium \\
\hline DNA & desoxyribonukleic acid \\
\hline FABP & fatty acid binding protein \\
\hline FGF & fibroblast growth factor \\
\hline GFP & green fluorescence protein \\
\hline HMG & high-mobility group \\
\hline HRP & horseradish peroxidase \\
\hline hTERT & human telomerase reverse transcriptase \\
\hline $\lg G$ & Immunglobulin G \\
\hline $\mathrm{kDa}$ & Kilodalton \\
\hline MMP & Matrix-Metalloprotease \\
\hline mRNA & messenger RNA \\
\hline
\end{tabular}


MSC mesenchymale Stammzelle

mTOR mammalian target of rapamycin

MW moleculare weight (engl.: Molekulargewicht)

OA Osteoarthrose

PAGE Polyacrylamidgelelektrophorese

PBS phosphate-buffered saline

PPAR Peroxisomen-Proliferator-aktivierte Rezeptoren

PVDF Polyvinylidenfluorid

qRT-PCR quantitative real-time polymerase chain reaction

RNA ribonucleic acid

RT Raumtemperatur

RUNX2 runt-related transcription factor 2

SDS Natriumdodecylsulfat

siRNA small interfering RNA

SOX9 SRY (sex determining region Y)-box 9

TBS-T tris-buffered saline and tween 20

TGF tissue growth factor

B2M beta-2 Mikroglobulin 


\section{Einleitung}

\subsection{Gelenkknorpel}

Gelenkknorpel befindet sich an den Enden langer Knochen und besteht aus einem speziellen Bindegewebe, dem hyalinen Knorpelgewebe. In den Gelenken schützt er die beiden aufeinandertreffenden Knochenenden vor zu großen Belastungen und verteilt die auftretenden Kräfte bei jeder Bewegung optimal. Seine glatte Oberfläche und der Gelenkflüssigkeitsüberzug vermindern die Reibung während Bewegungen. Gelenkknorpel besitzt weder Blutgefäße noch Nervenfasern und Lymphgefäße. So müssen alle anfallenden Stoffwechselprodukte und die Ernährung durch die extrazelluläre Matrix diffundieren (Kuettner 1992).

Der Gelenkknorpel besteht aus einer extrazellulären Matrix, in der die gewebsspezifischen Zellen, die Chondrozyten, eingebettet liegen. Die extrazelluläre Matrix besteht zu 70 \% aus Wasser. Dieses Wasser ist an Makromoleküle wie Kollagene, Proteoglykane (Aggrecan) und Glykoproteine gebunden. Die Kollagenfasern (50 \% des Trockengewichts) bilden ein dreidimensionales Netzwerk, in das die löslichen Komponenten eingebaut sind (Kuettner 1992). Die Kollagenfasern bestehen zu etwa $90 \%$ aus Kollagen-Typ 2, die restlichen 10 \% werden aus den Kollagen-Typen 6, 9, 10 und 11 gebildet (Eyre 2002; Mayne 1989).

Kollagen-Typ 2 gehört zur Untergruppe der Fibrillen-bildenden Kollagene. Es ist ein Homotrimer aus drei identischen a1(2)-Polypeptidketten. Kollagen-Typ 2 wird fast ausschließlich von Chondrozyten synthetisiert und durch $\mathrm{N}$ - und C-Proteinasen auf gleiche Weise wie Prokollagen 1 prozessiert (Bruckner und van der Rest 1994).

Kollagen-Typ 6 kommt im Gelenkknorpel in sehr geringen Mengen vor und bildet Mikrofibrillen in unmittelbarer Umgebung der Chondrone, der perizellulären Matrix aus. Am meisten ist Kollagen-Typ 6 in fibrokartilaginären Geweben wie Meniskus und Discus intervertebralis vertreten (Chu et al. 1990; Eyre 2002). 
Kollagen-Typ 9 ist ein nicht-fibrilläres Molekül und besteht aus drei helikalen und vier nicht-helikalen Domänen. Eine der Seitenketten kann mit einer ChondroitinsulfatKette glykosyliert werden und ist somit ein Proteoglykan (van der Rest und Mayne 1988). Des Weiteren ist Kollagen-Typ 9 ein Brückenmolekül, denn es ist in der Lage, sich mit Kollagen-Typ 2 kovalent zu verbinden (Eyre 2002; Wu et al. 1992).

Kollagen-Typ 10 ist wie Typ 9 ein kurzes helikales Molekül. Es ist innerhalb der kalzifizierten Schicht nahe der Tidemark zu finden und wird von hypertrophen Chondrozyten konstant synthetisiert (Poole und Pidoux 1989).

Für die spezielle Funktion des Knorpels, seine enorme Druckelastizität, sind vor allem die Proteoglykane verantwortlich. Diese wasseranziehenden Makromoleküle sind in das eher trockene (underhydrated) Netzwerk der Kollagenfasern eingebettet (Kuettner 1992). Das vorherrschende Proteoglykan des Gelenkknorpels ist Aggrecan. Aggrecan besteht aus einem Kernprotein, an das Glykosaminoglykan-Seitenketten und Oligosaccharide kovalent gebunden sind. Die Glykosaminoglykan-Ketten sind Keratansulfat und Chondroitinsulfat und machen etwa 90 \% des Gesamtgewichts von Aggrecan aus. Gemeinsam mit nicht-kovalent gebundenem Hyaluronan entstehen riesige Proteoglykan-Aggregate (Morgelin et al. 1995). Neben Aggrecan finden sich im Gelenkknorpel noch die Proteoglykane Biglykan, Decorin (Fisher et al. 1989) und Fibromodulin (Oldberg et al. 1989). Sie interagieren mit den Makromolekülen der extrazellulären Matrix und nehmen so Einfluss auf deren Struktur und Funktion (Kuettner 1992).

Die negativ geladenen Proteoglykane ziehen sehr viel Wasser an. Dies verleiht dem Gelenkknorpel seinen Quelldruck und seine Elastizität. Bei Belastung des Gelenks wird so lange Wasser aus dem Knorpelgewebe in die Synovialflüssigkeit gepresst und damit die Proteoglykane so stark komprimiert, bis der Quelldruck und die Anziehungskraft für das Wasser ausgeglichen sind. Wird das Gelenk wieder entlastet, saugen die Proteoglykane das Wasser wieder auf, bis der Quelldruck wieder ausgeglichen ist (Huber et al. 2000; Morgelin et al. 1995). 


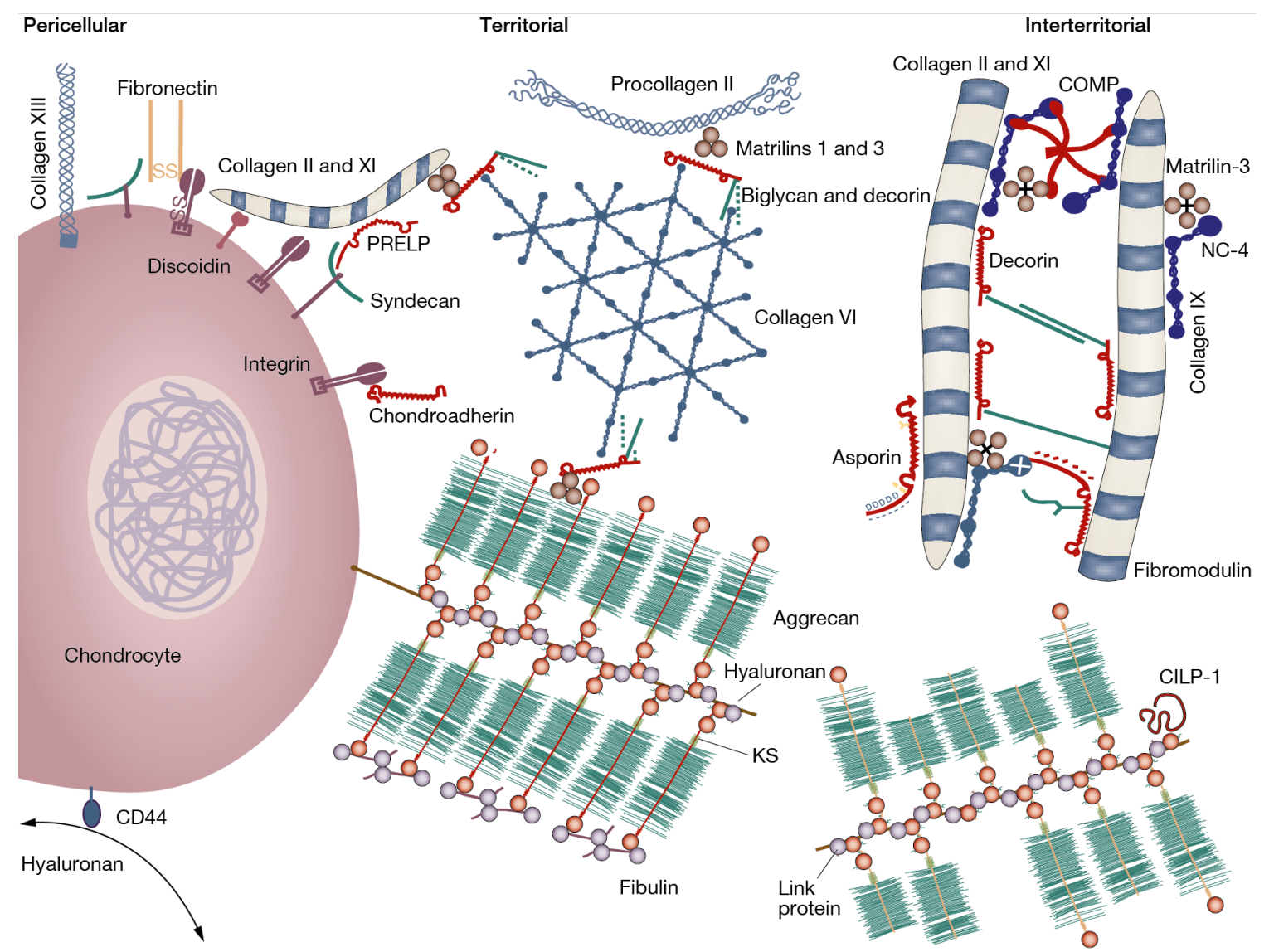

Abbildung 1: Die molekulare Organisation des gesunden Knorpels. Die Chondrozyten werden von einer Matrix umgeben, die durch ihre Distanz zur Zelle in Zonen eingeteilt wird. Die perizelluläre Matrix befindet sich unmittelbar um die Zelle. Die Moleküle dieser Zone interagieren mit Rezeptoren auf der Zelloberfläche: z.B. bindet Hyaluronan an CD44. Etwas weiter entfernt liegt die territoriale Matrix und am weitesten entfernt schließlich die interterritoriale Matrix. Die Kollagen-Typen und die daran bindenden Moleküle unterscheiden sich in jeder Zone. Abkürzungen: CILP-1 = cartilage intermediate layer protein 1; COMP = cartilage oligomeric matrix protein; $C S$ = chondroitin sulfate; $K S$ = keratan sulfate; PRELP = proline-arginine-rich repeat protein. Abbildung entnommen und modifiziert nach Heinegard und Saxne (2011) (S. 52).

Die Chondrozyten machen als zellulärer Anteil des Gelenkknorpels nur einen Volumenanteil von etwa $5 \%$ aus (Kuettner 1992). Sie exprimieren alle Bestandteile des Knorpelgewebes und differenzieren sich während der Skelettentwicklung aus mesenchymalen Stammzellen (MSCs). Die MSCs werden durch Signale wie Zell-Zellund Zell-Matrix-Interaktionen (Goldring et al. 2006) sowie Wachstums- und Transkriptionsfaktoren (Wuelling und Vortkamp 2010) angeregt zu migrieren und zu proliferieren. Die Chondrozyten sind in sogenannten Chondronen angeordnet und 
innerhalb dieser Chondrone von einer perizellulären Matrix umgeben. Die Zahl der Chondrozyten je Chondron variiert zwischen den Schichten. Die Chondrone und die umgebende perizelluläre Matrix werden auch als Territorium bezeichnet, die Bereiche dazwischen als Interterritorien (Poole 1997). Eine Besonderheit der Chondrozyten ist inr fehlender Zell-Zell-Kontakt und somit eine erschwerte Kommunikation mit anderen Zellen. Adulte Chondrozyten teilen sich so gut wie nicht mehr. Dennoch sind sie metabolisch sehr aktiv, denn sie halten das Gleichgewicht der extrazellulären Matrix aufrecht (Kuettner 1992).

Mikroskopisch lässt sich der Gelenkknorpel horizontal von außen nach innen in eine oberflächliche, mittlere, tiefe und eine kalzifizierte Schicht einteilen. Charakteristisch für die oberflächliche Schicht sind tangential angeordnete, dünne Kollagenfasern in Verbindung mit einer hohen Konzentration an Decorin und nur wenig Aggrecan. Die Chondrozyten sind hier klein und abgeflacht. In der mittleren Schicht finden sich dickere, radial angeordnete Kollagenfaserbündel und rundere Chondrozyten. In der tiefen Schicht sind die Kollagenfaserbündel am dicksten und ebenfalls radial angeordnet. In dieser Schicht sind die Chondrozyten in Gruppen (Cluster) oder Säulen angeordnet. Die kalzifizierte Schicht liegt direkt dem Knochen auf und besitzt runde Chondrozyten in nicht-kalzifizierten Lakunen, umgeben von einer kalzifizierten Matrix ohne Proteoglykane oder Kollagenfasern. Die im Lichtmikroskop sichtbare gewellte Linie zwischen der tiefen Schicht und der kalzifizierten Schicht wird Tidemark genannt (Goldring und Marcu 2009; Poole 1997).

\subsection{Osteoarthrose}

\subsubsection{Epidemiologie der Osteoarthrose}

Die Osteoarthrose $(\mathrm{OA})$ ist eine degenerative Verschleißerkrankung der Gelenke. Im englischen Sprachraum wird die OA auch als Osteoarthritis bezeichnet. Epidemiologische Aussagen zur OA variieren zum Teil erheblich aufgrund unterschiedlicher Definitionen der OA, des jeweiligen untersuchten Gelenks und der untersuchten Population. Weltweit leiden, Stand 2012, mehr als 250 Millionen Menschen an einer OA des 
Knies. Dies entspricht 3,6 \% der Weltbevölkerung (Vos et al. 2012). 2008 lag in den USA das Lebenszeitrisiko, an einer symptomatischen OA des Knies zu erkranken, bei etwa $40 \%$ bei Männern und etwa $47 \%$ bei Frauen (Murphy et al. 2008). In Deutschland lag die Lebenszeitprävalenz der Arthrose im Jahr 2012 bei Frauen bei etwa $28 \%$ und bei Männern bei etwa 20 \% (Robert Koch-Institut 2014). Mit steigendem Alter tritt die Erkrankung deutlich häufiger auf (Robert Koch-Institut 2013).

\subsection{2 Ätiologie und Pathologie der Osteoarthrose}

Die OA wird durch die Degeneration des Gelenkknorpels, eine Entzündung im Gelenk, einhergehend mit einer Synovialitis sowie Veränderungen im periartikulären und subchondralen Knochen charakterisiert. Die am häufigsten betroffenen Gelenke sind die Hände, die Kniegelenke, die Hüftgelenke und die Wirbelsäule (Goldring und Goldring 2007). Die klinischen Symptome sind Funktionseinschränkungen zusammen mit Schmerzen, Entzündung, Gelenksteifigkeit und Mobilitätsverlust (Felson 2006). Das Auftreten dieser Symptome, gemeinsam mit radiologischen Befunden, definiert die symptomatische OA (Zhang und Jordan 2010). Allerdings kann eine OA auch schon vorliegen, wenn radiologisch noch keine Veränderungen sichtbar sind (Felson 2006). Die Ursachen der OA können in zwei Gruppen eingeteilt werden: Entweder wirkt eine abnormale Belastung auf normalen Knorpel oder eine normale Belastung auf abnormalen Knorpel (Goldring und Goldring 2007). Die Hauptrisikofaktoren der Knie-OA sind Gelenkfehlstellung, Übergewicht, vorangegangene Knieverletzungen, OA in anderen Gelenken, das weibliche Geschlecht, fortgeschrittenes Alter sowie sport- und berufsbedingt erhöhte Belastungen der Gelenke (Blagojevic et al. 2010). Bei einer Knie-OA treten die folgenden pathologischen Veränderungen auf: Zersetzung des Gelenkknorpels, Verdickung des subchondralen Knochens, Bildung von Osteophyten, Synovialentzündung, Degeneration des Bandapparates und der Menisken sowie Hypertrophie der Gelenkkapsel. Zusätzlich können Veränderungen in den umliegenden Muskeln, Nerven, Schleimbeuteln und Fettpolstern vorliegen (Loeser et al. 2012). Im Röntgenbild erscheinen die Veränderungen als Verengungen des Gelenkspalts, Osteophyten, Zysten und subchondrale Sklerose (Guilak et al. 2004). 

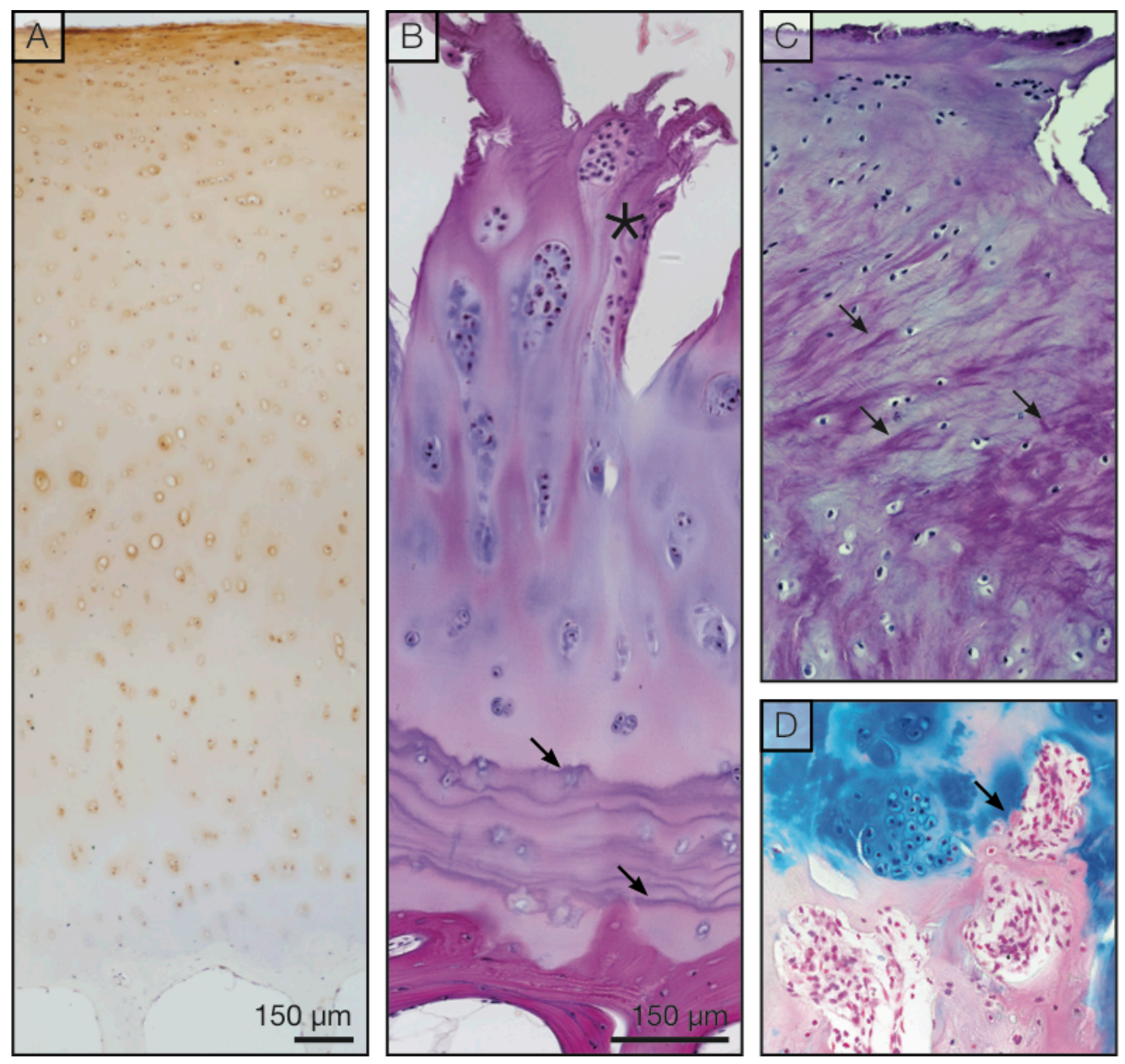

Abbildung 2: Histologisches Bild der Osteoarthrose (OA). Gelenkknorpel eines Patienten nach totaler Kniearthroplastik. A: Gesunder Gelenkknorpel. B: Spätes Stadium der OA. Auffallend ist die Multiplikation der Grenzlinie (Pfeile) sowie die Fissuren und die ChondrozytenCluster (Stern). C: Fibrokartilaginäres Ersatzgewebe mit narbenartiger Erscheinung (Pfeile). D: Mesenchymales Gewebe dringt von unterhalb der Grenzlinie aus dem Knochenmark in den hyalinen Knorpel ein (Pfeil). Abbildung nach freundlicher Bereitstellung entnommen aus der Dissertation von Gökhan Cingöz (2015) (S.7).

Histologisch sind die charakteristischen Veränderungen einer OA deutlich erkennbar. Die Chondrozyten formieren sich als Folge von erhöhter Zellproliferation und allgemein erhöhter Syntheseaktivität zu Clustern. An der Knorpeloberfläche kommt es zu Fibrillation und Bildung von Fissuren, die kalzifizierte Zone verdickt sich, und es kommt zur Multiplikation der Grenzlinie (Schminke und Miosge 2014). Die erhöhte mechanische Beanspruchung und die Synovialentzündung führen zu einer Fehlregu- 
lation der Chondrozyten und stören damit das Gleichgewicht zwischen anabolen und katabolen Aktivitäten (Goldring und Goldring 2007). Die Reparaturmechanismen im erkrankten Gelenk werden von der Matrixzerstörung und der Bildung von nur wenig funktionellem fibrokartilaginärem Ersatzgewebe mit mehr Kollagen-Typ 1 überlagert (Muhammad et al. 2013). Außerdem scheint Kollagen-Typ 4 in osteoarthritischem Gewebe sowohl beim Menschen als auch in Tierexperimenten erhöht zu sein (Kuettner 1992). Auch die Synthese von Kollagen-Typ 10 ist in osteoarthritischem Knorpel erhöht und wird hier von Chondrozyten in oberflächlicheren Schichten des Knorpels, speziell in Zell-Clustern, gebildet (Gannon et al. 1991). Die Chondrozyten bilden Entzündungsmediatoren wie Zytokine und Chemokine sowie proteolytische Enzyme, die den Gelenkknorpel und das umliegende Gewebe zerstören (Wieland et al. 2005). Zu den hauptverantwortlichen Proteasen zählen die MatrixMetalloproteasen (MMP-1, MMP-3, MMP-9, MMP-13, MMP-14) und die Aggrecanasen ADAMTS4, ADAMTS5 und ADAMTS9 (a disintegrin and metalloproteinase with thrombospondin-like motifs) (Murphy und Nagase 2008). Die erhöhte Expression von Regulatorproteinen, Matrixproteinen, Stress- und Apoptosemarkern und Transkriptionsfaktoren beeinflusst die Zellen und Gewebsveränderungen zusätzlich (Goldring und Marcu 2009; Murphy und Nagase 2008). Ist der Gelenkknorpel schließlich stark zerstört, sind die Chondrozyten nicht mehr in der Lage, den komplexen Aufbau des Gelenkknorpels neu zu bilden (Goldring und Goldring 2007).

\subsubsection{Therapieansätze}

Alle Therapieansätze zielen darauf ab, Schmerzen zu lindern und die Bewegungsfähigkeit zu verbessern oder wiederherzustellen. Es lassen sich konservative von operativen Maßnahmen unterscheiden. Konservative, nicht-operative Behandlungsansätze wie Lebensstilveränderung (Gewichtsreduktion), Bewegungsprogramme oder Physiotherapie sowie medikamentöse Schmerztherapie lindern zwar die Schmerzen und verbessern die Beweglichkeit, führen jedoch nicht zur Heilung der OA (Mankin und Buckwalter 1996). Operationen sind dann indiziert, wenn eine Verbesserung der Krankheitssymptome mit konservativen Maßnahmen nicht möglich ist. Bei diesen operativen Behandlungen werden gelenkerhaltende von gelenkersetzen- 
den Operationen unterschieden. Bei leicht- bis mittelgradiger OA wird bei arthroskopischen Eingriffen das Gelenk gespült (Lavage), die Knorpeloberflächen geglättet (Shaving) und störende Knochenwucherungen und freie Gelenkkörper entfernt (Débridement) (Robert Koch-Institut 2013). Knochenmarkstimulierende Techniken wie die Knochenanbohrung (Pridie-Technik), Mikrofrakturierung oder Abrasionsarthroplastik führen durch eine Verletzung an der Grenzlinie zwischen Knochen und Knorpel zu spontanen Reparaturprozessen. Dabei sollen Knochenmarksstammzellen in den Gelenkknorpel einwandern und damit die Knorpelneubildung anregen (Johnson 1986; Kreuz et al. 2006; Robert Koch-Institut 2013; Steadman et al. 2003).

Zu den Methoden, deren Ziel die Gelenkflächenwiederherstellung ist, zählen die autologe osteochondrale Transplantation (AOT) und die autologe Chondrozytentransplantation (ACT). Hierbei sollen tiefe Knorpelschädigungen mit körpereigenem (autologem) Gewebe saniert werden (Robert Koch-Institut 2013). Bei der AOT werden zylinderförmige Knochen-Knorpel-Stücke aus dem gesunden Teil des Femurkondylus herausgestanzt, kultiviert und an der defekten Stelle mosaikartig eingesetzt. Bei der ACT werden autologe Chondrozyten ebenfalls von einer nicht betroffenen Stelle des Gelenks entnommen, für zwei bis drei Wochen kultiviert und dann an der erkrankten Stelle injiziert (Muller et al. 2010). Bei sehr großen Defekten mit erheblicher Symptomatik oder wenn alle anderen Therapieansätze keine Wirkung zeigen, ist ein künstlicher Gelenkersatz indiziert (Lohmander und Roos 2007).

Da die aktuellen Therapiemethoden nicht die gewünschten Erfolge aufweisen und bei der Regeneration fibrokartilaginäres Ersatzgewebe anstelle von hyalinem Gelenkknorpel entsteht, werden in Zukunft die Erfolge auf dem Gebiet des Tissue Engineering eine immer größere Rolle spielen (Cucchiarini et al. 2014).

\subsection{Chondrogene Progenitorzellen}

Im pathologischen Gewebe der OA sind drei unterschiedliche Chondrozytentypen bekannt: gesunde Chondrozyten, die kontinuierlich degenerieren, degenerierte Chondrozyten, die abgebaut werden und schließlich fibroblastenartige Chondrozyten. Letztere werden nicht abgebaut, sondern ihre Anzahl steigt stetig. Außerdem sind die fibroblastenartigen Chondrozyten durch die Bildung von fibrokartilaginärem 
Narbengewebe an Regenerationsprozessen beteiligt, indem sie Kollagen-Typ 1 synthetisieren. Sie sind allerdings nicht in der Lage, das Gelenkknorpel-typische Kollagen-Typ 2 zu bilden (Tesche und Miosge 2005).

Koelling et al. (2009) konnten fibroblastenartige Chondrozyten aus erkranktem Gelenkknorpelgewebe isolieren und relevante Stammzellcharakterisitika wie hohe Zellteilungsrate, Stammzellmarker, Migrationspotenzial und Multidifferenzierungspotenzial zeigen. So lassen sich diese Vorläuferzellen bei geeigneten Bedingungen zu Adipozyten, Osteozyten und Chondrozyten differenzieren. Aufgrund des chondrogenen und migratorischen Potenzials dieser Zellen wurden sie chondrogene Progenitorzellen (CPCs) genannt (Koelling et al. 2009).

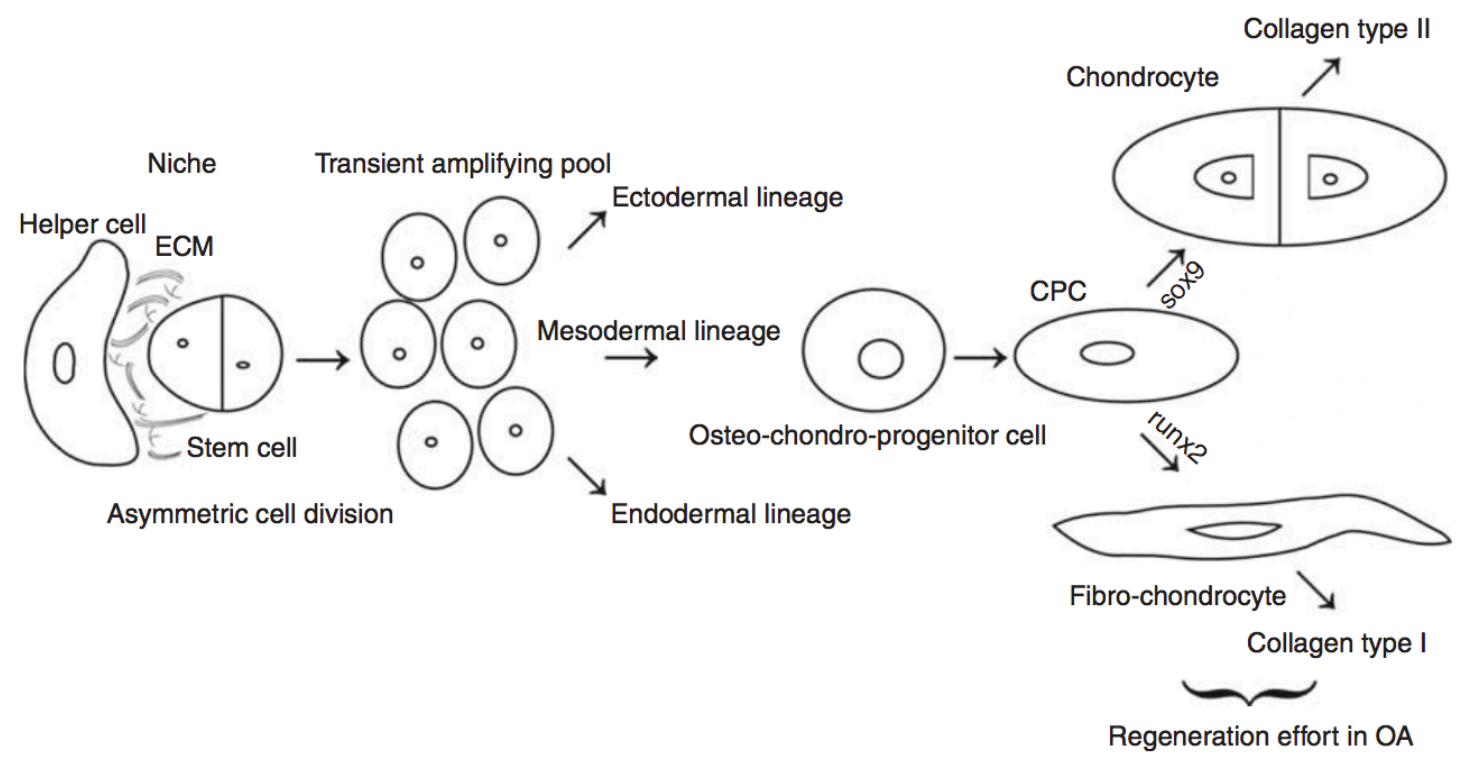

Abbildung 3: Das Konzept der Progenitorzellen in situ. Die Stammzelle befindet sich in Nischen und entsendet Zellen, die sich während eines Reparationsprozesses zu osteochondralen Progenitorzellen entwickeln. Diese Zellen werden schließlich zu CPCs und produzieren Kollagen-Typ 1. Das Ziel ist es, diese Zellen so zu manipulieren, dass sie sich zu Chondrozyten differenzieren, die Kollagen-Typ 2 und hyalinen Knorpel bilden. Dies könnte über RUNX2 und SOX9 erreicht werden. Entnommen und modifiziert nach Muhammad et al. (2013) (S.5).

In vitro ist es bereits möglich, durch einen Knockdown von runt-related transcription factor 2 (RUNX2) das chondrogene Potenzial der CPCs zu erhöhen. Dabei kommt es 
zu einer Hochregulierung der Expression von SRY (sex determining region Y)-box 9 (SOX9) und Kollagen-Typ 2 wird vermehrt exprimiert. Bis heute ist es jedoch noch nicht gelungen, die CPCs so zu modifizieren, dass sie funktionierendes hyalines Knorpelgewebe in vivo bilden (siehe Abbildung 3). Ein Weg könnte sein, das chondrogene Potenzial der bereits vorhandenen Reparaturzellen im erkrankten Knorpelgewebe zu steigern (Muhammad et al. 2013).

\subsection{Regulation der Chondrogenese}

Als Chondrogenese bezeichnet man die ersten Schritte der Skelettentwicklung. Dabei kommt es zur Kondensation mesenchymaler Stammzellen mit anschließender Differenzierung zu Chondroprogenitorzellen, aus denen sich das Knochen- und Knorpelgewebe entwickelt. Dieser Prozess wird durch diverse Kontrollmechanismen gesteuert. Zu diesen zählen Zellinteraktion mit der Umgebung, Wachstums- und Differenzierungsfaktoren und andere Einflüsse, die zelluläre Signalwege und die Transkription spezifischer Gene einleiten oder unterdrücken (Goldring et al. 2006).

Die Chondrogenese wird durch das enge Zusammenspiel diverser Signalkaskaden, Wachstums- und Transkriptionsfaktoren gesteuert. Hierzu zählen die Wachstumsfaktoren fibroblast growth factor (FGF), transforming growth factor (TGF)- $\beta$, bone morphogenic protein (BMP) sowie die Signalkaskaden Hedgehog, Wnt und Smad. Die beiden hauptverantwortlichen Transkriptionsfaktoren bei der osteochondrogenen Differenzierung sind SOX9 und RUNX2 (Lefebvre und Smits 2005; Long 2012; Wuelling und Vortkamp 2010).

Die Gruppe der SOX-Proteine gehört zur high-mobility-group- (HMG-) Box-Familie. Sie wurden im Zuge der Identifizierung von Sry, das für den testis-determining-factor (TDF) kodierende Gen, das auf dem Y-Chromosom lokalisiert ist, entdeckt. Sry besitzt eine Domäne, die Ähnlichkeit zu den DNA-bindenden Domänen der chromosomalen Nichthistonproteine HMG-1 und HMG-2 aufweist. Die Sox-Proteine weisen eine Übereinstimmung der Aminosäuren mit der HMG-Domäne von Sry von mindestens 50 \% auf. Die HMG-Domäne wird auch als Sry-Box bezeichnet. Diese Box gab den Sox-Proteinen ihren Namen (Wegner 1999). 
Neben einer geschlechtsbestimmenden Funktion spielt SOX9 eine wesentliche Rolle in der Chondrogenese und reguliert diverse Stadien der Knorpelentwicklung. Die Überexpression von SOX9 treibt die Chondrogenese in den MSCs an. Dies geschieht zum Teil durch direkte Aktivierung der Transkription von Genen, die für die Knorpelentwicklung notwendig sind (Kiefer 2007). Fehlt SOX9, so bleibt die mesenchymale Kondensation aus, aber auch nach der mesenchymalen Kondensation wird SOX9 für die weitere Differenzierung der Chondrozyten benötigt (Akiyama et al. 2002). So entstehen aus den MSCs durch das Einwirken von SOX9 die Osteo-ChondroprogenitorZellen (Akiyama et al. 2005). In den Prächondroblasten und Chondroblasten wird weiterhin SOX9 exprimiert. In hypertrophen Chondrozyten wird SOX9 nicht mehr exprimiert (Lefebvre und Smits 2005).

Heterozygote Mutationen im SOX9-Gen sind der Grund für das skeletale Fehlbildungssyndrom Campomele-Dysplasie beim Menschen (Wagner et al. 1994). Charakteristisch für die Erkrankung sind allgemein fehlende Mineralisation, das Abknicken der langen Röhrenknochen, hypoplastische Schädelknochen, Fehlbildungen des Beckens und Klumpfüße (Sock et al. 2003). Dies unterstreicht die fundamentale Rolle von SOX9 bei der Knorpelentwicklung.

Lefebvre et al. (1997) konnten zeigen, dass die Expression von Kollagen-Typ 2 eng mit der von SOX9 korreliert. SOX9 bindet direkt an den Enhancer (Transkriptionsverstärker) für COL2a, das Gen für Kollagen-Typ 2 (Lefebvre et al. 1997).

RUNX2 oder core binding factor 1 (Cbfa1) ist ein Transkriptionsfaktor und gehört zu den Core Binding Factors (CBF). Die CBFs sind eine Gruppe von Transkriptionsfaktoren, die aus einer DNA-bindenden a-Untereinheit und einer nichtbindenden $\beta$ Untereinheit bestehen (Otto et al. 1997). RUNX2 wird in MSCs exprimiert und reguliert als ein Osteoblasten-spezifischer Transkriptionsfaktor die Osteoblastendifferenzierung (Ducy et al. 1997; Jonason et al. 2009). Homozygote RUNX2-KnockoutMäuse zeigen eine gestörte Entwicklung der Osteoblasten und es bilden sich keine Knochen. Bei Mäusen mit heterozygoten Mutationen in RUNX2 zeigt sich eine Hypoplasie der Schlüsselbeine sowie verspätete Ossifikation der Schädelknochen. Diese spezifischen Knochendefekte bei Mäusen stellen ein Modell für die Cleidocraniale Dysplasie beim Menschen dar (Otto et al. 1997). Diverse Mutationen des RUNX2- 
Gens wie Deletion, Insertion, Missense Mutationen oder das heterozygote Fehlen von RUNX2 führen zur Cleidocranialen Dysplasie (Mundlos et al. 1997).

Während der OA steigt die Expression von RUNX2 im Vergleich zu der in gesundem Knorpelgewebe. Die erhöhte RUNX2-Expression führt außerdem zu einer vermehrten Sezernierung von MMP-13. Somit scheint die RUNX2-Expression ein entscheidender Schritt in der Entwicklung einer OA zu sein (Wang et al. 2004). Die gemeinsame Hochregulierung der Gen-Expression von Col10a1, MMP-13 und RUNX2 in den tiefen Zonen des OA-Knorpels könnte zur Erweiterung der kalzifizierten Knorpelzone führen (Goldring und Goldring 2010).

SOX9 und RUNX2 sind die Haupttranskriptionsfaktoren in Osteogenese und Chondrogenese. Sie können miteinander interagieren und SOX9 ist in der Lage, die Aktivierung von RUNX2 zu inhibieren und umgekehrt (Cheng und Genever 2010). Durch den Knockdown von RUNX2 in CPCs wird das chondrogene Potenzial der CPCs durch Hochregulierung der Expression von SOX9 und Kollagen-Typ 2 erhöht (Muhammad et al. 2013).

Der Zusammenhang von SOX9 und RUNX2 und deren Schlüsselrolle in der Osteobzw. Chondrogenese zeigen, dass beide ein mögliches Ziel für die Behandlung der OA darstellen.

\subsection{Fatty Acid Binding Protein 5}

In einer Doktorarbeit dieser Arbeitsgruppe (Orale Biologie und Geweberegeneration) wurden mithilfe von Knockdown- sowie Pull-Down-Versuchen Co-Regulatoren von RUNX2 und SOX9 identifiziert. In der Arbeit sind eine Reihe potenzieller Interaktionspartner für RUNX2 und SOX9 aufgeführt (Cingöz 2015). Fatty Acid Binding Protein 5 (FABP5) konnte dabei als ein potenzieller Bindungspartner von RUNX2 identifiziert werden. In der vorliegenden Arbeit wurde das humane FABP5, auch epidermales (E-) FABP oder Keratinocyten (K-) FABP genannt, in chondrogenen Progenitorzellen (CPCs) ausgeknockt und die Auswirkungen dieses Knockdowns auf die CPCs untersucht. 
Die humanen intrazellulären FABPs werden in den meisten Geweben exprimiert. Es sind kleine zytosolische Proteine mit einer Größe von 15 kDa, die unveresterte langkettige Fettsäuren und andere Liganden binden können (Thumser et al. 2014). Alle FABPs besitzen eine hohe Affinität zu einer einzigen gesättigten oder ungesättigten langkettigen Fettsäure (14 C-Atome), mit der Ausnahme des Leber-FABP (FABP1), das zwei Fettsäuren oder andere hydrophobe Moleküle binden kann (Storch und Thumser 2010). FABPs scheinen durch die Kontrolle des Transports, des Metabolismus und der Speicherung von Fettsäuren eine zentrale Rolle bei der Regulation von Fettstoffwechsel, Entzündungsprozessen und Energiehaushalt zu spielen (Storch und McDermott 2009). Fettsäuren ihrerseits können durch verschiedene Mechanismen die Gentranskription der Zelle beeinflussen. Diese Mechanismen können Transkriptionsfaktoren modifizieren, an sie binden und sie damit aktivieren, die Stabilität der mRNA beeinflussen oder sich auch auf die Expression von Transkriptionsfaktoren auswirken (Chmurzynska 2006; Duplus et al. 2000). Es sind neun verschiedene Genvarianten der FABPs bekannt, die jeweils nach dem Ort, an dem sie entdeckt wurden, benannt sind. Viele der FABPs werden jedoch in mehreren Geweben exprimiert und deshalb wurde eine nummerische Nomenklatur eingeführt (Storch und McDermott 2009; Storch und Thumser 2010).

Die kleinen Proteine zeigen nur eine geringe Homologie in der Aminosäurensequenz (20-70 \%), gleichen sich aber zum größten Teil in ihrer Tertiärstruktur. Allen gemeinsam ist die zehnsträngige antiparallele $\beta$-Fass-Struktur. Innerhalb des $\beta$-Fasses befindet sich die Bindungsstelle für den Liganden. Auf der einen Seite dieser Bindungsstelle befindet sich ein N-terminales helix-turn-helix-Motif, das wohl die wichtigste Zugangsstelle für die langkettigen Fettsäuren darstellt (Storch und Thumser 2010).

FABP5 wurde von Madsen et al. 1992 erstmals in Keratinozyten von an Psoriasis leidenden Patienten entdeckt. In diesen Keratinozyten waren die FABP5-Level extrem erhöht und damit auch der Transport und Metabolismus von Fettsäuren verändert. Dies entspricht den üblichen Beobachtungen in psoriatischer Haut, in der Lipide, Phospholipide und freie Arachnoidinsäure erhöht sind (Madsen et al. 1992).

Die physiologischen Liganden von FABP5 sind noch nicht vollständig bekannt. Die gesättigte $\mathrm{C}_{18}$-Stearinsäure zeigt höchste Affinität zu FABP5, während sich mit stei- 
gender Kettenlänge und steigendem Grad der ungesättigten Bindungen die Affinität verringert (Hohoff et al. 1999).

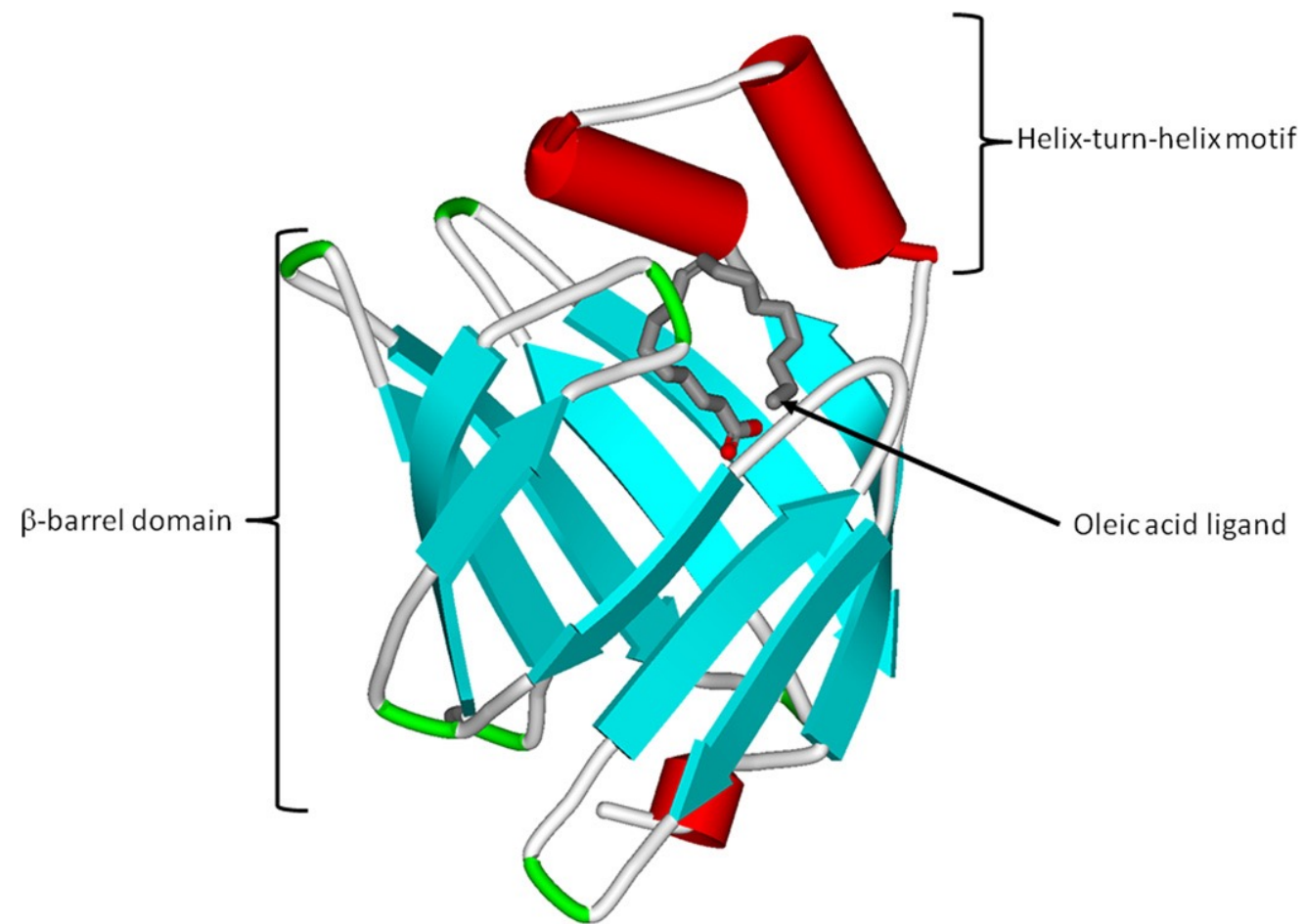

Abbildung 4: Kristallstruktur des humanen FABP5 mit einer gebundenen Fettsäure (oleic acid ligand). Die Proteinstruktur zeigt die in allen FABPs vorkommende beta-Fass-Struktur und das N-terminale helix-turn-helix-Motif. Entnommen aus Storch und Thumser (2010) (S. 32680).

FABP5 wird nicht nur im Epithelgewebe gebildet, sondern auch in vielen anderen Geweben wie Brustdrüse, Gehirn, Niere, Lunge, Adipozyten, Zunge und Hoden exprimiert (Smathers und Petersen 2011).

Für die Entwicklung des Gehirns scheint FABP5 eine wichtige Rolle zu spielen, denn in den pränatalen und frühen postnatalen Neuronen ist die Expression von FABP5 deutlich erhöht (Liu et al. 2010). FABP5 scheint außerdem bei der über PeroxisomenProliferator-aktivierte Rezeptoren (PPAR)- $\beta / \delta$ vermittelten Induktion der Keratinozytendifferenzierung beteiligt zu sein (Tan et al. 2002).

Bando et. al (2014) konnten FABP5 in den Wachstumsplatten der langen Knochen junger Mäuse nachweisen. Hier scheint FABP5 den intrazellulären Transport von 
Fettsäuren, vor allem von Omega-3-Fettsäuren, zu übernehmen. Die Fettsäuren gelangen in der Zelle zu verschiedenen Zielen; zu den Mitochondrien und zum Zellkern. Auch hier scheint die transkriptionelle Regulation der endochondralen Ossifikation im Zusammenspiel mit PPAR $\beta / \delta$ beeinflusst zu werden (Bando et al. 2014).

Durch ihre Funktionen auf den Fettstoffwechsel, können die FABPs als Adipokine angesehen werden (Kralisch und Fasshauer 2013). Außerdem stehen die FABPs in engem Zusammenhang mit Übergewicht. So sind beispielsweise FABP4 und FABP5 bei Übergewichtigen erhöht (Canas et al. 2015) und FABP5 begünstigt zudem die Entwicklung einer ernährungsbedingen Adipositas (Shibue et al. 2015). Dass Übergewicht die Entstehung einer OA begünstigt, ist bekannt (Oliveria et al. 1999). Die komplexe Ätiologie dieses Zusammenhangs ist bis heute jedoch noch nicht geklärt (Thijssen et al. 2015).

Die Tatsachen, dass FABP5 ein potenzieller Interaktionspartner von RUNX2 und FABP5 gleichzeitig bei der Entstehung von Übergewicht sowie beim Fettstoffwechsel, Entzündungsprozessen und Energiehaushalt beteiligt ist, geben Hinweis auf die mögliche Rolle, die FABP5 bei den Prozessen der OA spielt. 


\subsection{Fragestellung und Ziele dieser Arbeit}

In der vorgelegten Arbeit wurde der Einfluss von FABP5 auf SOX9 und RUNX2 in CPCs untersucht. Durch den Nachweis von Kollagen-Typ 1 sollte die chondrogene Differenzierung der CPCs gezeigt werden. Hierfür wurden humane Knorpelzellen aus erkrankten Gelenken verwendet und kultiviert. Die CPCs entstammten aus osteoarthritischem Knorpel.

Durch den Knockdown von FABP5 in den CPCs mit siRNA wurden die Effekte sowohl auf genetischer Ebene durch quantitative real-time PCR als auch auf Proteinebene durch Western Blot analysiert. 


\section{Material und Methoden}

\subsection{Immunhistochemie}

\subsubsection{Immunhistochemische Darstellung von FABP5 im Knorpel}

Die Methode der Immunhistochemie ermöglicht den Nachweis des Proteins FABP5 in Knorpel und Knochen. Mithilfe des HiDef Detection Alkalische Phosphatase Polymer Systems (Ca. No. 962D-12) von Cell Marque (Rocklin, USA) kann der Antikörper (AK) gegen FABP5 in den Gewebeschnitten sichtbar gemacht werden. Dabei erkennt ein sekundärer AK den primären AK. Anschließend bindet die Alkalische Phosphatase an den sekundären AK. Die Alkalische Phosphatase reagiert mit dem Chromogen PermaRed, sodass die gesuchten Proteine mikroskopisch sichtbar werden. In Tabelle 1 ist das Protokoll der immunhistochemischen Reaktion aufgelistet.

\subsubsection{Verwendetes Knorpelgewebe}

Aus in der Arbeitsgruppe bereits vorhandenen, in Paraffin eingebetteten Knorpelproben wurden mithilfe eines Mikrotoms (Leica, Nussloch, D) $4 \mu \mathrm{m}$ dünne Schnitte angefertigt. Anschließend wurden die Schnitte mit einem Pinsel in ein $37^{\circ} \mathrm{C}$ warmes Wasserbad gelegt und mit einem Objektträger (Thermo Scientific, Braunschweig, D) aufgenommen. Auf eine $42{ }^{\circ} \mathrm{C}$ warme Wärmeplatte wurden die Schnitte für 30 min gelegt und danach für $48 \mathrm{~h}$ im Wärmeschrank (Heraeus, Hanau, D) getrocknet. Bei den verwendeten Gewebeproben handelte es sich um Knorpel- und Knochengewebe aus osteoarthritischen Kniegelenken. 
Tabelle 1: Protokoll Immunhistochemie

\begin{tabular}{|c|c|c|}
\hline Schritt & Lösung/ Substrat & Zeit \\
\hline Entparaffinieren & Xylol I & $2 \times 10 \mathrm{~min}$ \\
\hline Alkoholreihe & Ethanol $100 \%$ - $50 \%$ & je 5 min \\
\hline Waschen & TBS-T & $5 \mathrm{~min}$ \\
\hline Blocken & Universal-Block & $30 \mathrm{~min}$ \\
\hline Waschen & TBS-T & $3 \times 3$ min \\
\hline Antigendemaskierung & Protaqs bei $60^{\circ} \mathrm{C}$ & $30 \mathrm{~min}$ \\
\hline Waschen & TBS-T & $3 \times 3$ min \\
\hline Blocken & $1 \%$ BSA/TBS & $10 \mathrm{~min}$ \\
\hline Primärer Antikörper & FABP5 1:100 & Über Nacht bei RT \\
\hline Waschen & TBS-T & $3 \times 3 \mathrm{~min}$ \\
\hline Sekundärer Antikörper & HiDef Amplifier & $30 \mathrm{~min}$ \\
\hline Waschen & TBS-T & $3 \times 3$ min \\
\hline Polymer & HiDef Polymer & $20 \mathrm{~min}$ \\
\hline Waschen & TBS-T & $3 \times 3 \mathrm{~min}$ \\
\hline Chromogenfärbung & PermaRed & $4 \min$ \\
\hline Waschen & TBS-T & $10 \min$ \\
\hline Gegenfärbung & Lichtgrün (Verdünnung 1:4) & $10 \mathrm{sec}$ \\
\hline Waschen & 1 \% Essigsäure & $5 \mathrm{sec}$ \\
\hline \multirow[t]{2}{*}{ Dehydrieren } & Ethanol $50 \%-100 \%$ & je 3 min \\
\hline & Xylol & $2 \times 5 \min$ \\
\hline
\end{tabular}

Nach dem Dehydrieren wurden die Präparate mit Eukitt und einem Glas-Coverslip (Thermo Scientific, Braunschweig, D) gedeckelt. Die angefärbten Schnitte konnten nun unter dem Mikroskop (\#415500-0004-000, Carl Zeiss, Göttingen, D) beurteilt werden. 


\subsection{Zellkultur}

\subsubsection{Herkunft der CPCs}

Die humanen CPCs wurden aus hyalinem Knorpel osteoarthritischer Kniegelenke nach dem Protokoll von Koelling et al. (2009) gewonnen. Die Patienten waren zwischen 65 und 75 Jahre alt und litten an einer OA im späten Stadium und unterzogen sich einer totalen Kniearthroplastik, die im akademischen Lehrkrankenhaus NeuMariahilf in Göttingen durchgeführt wurde. Vor der Operation wurden die Patienten über den Aufbau und die Ziele der Studien aufgeklärt und gaben eine schriftliche Einverständniserklärung zur Verwendung ihrer Proben ab. Die Studie wurde durch die Ethikkommission der medizinischen Fakultät der Universität Göttingen genehmigt (Antragsnummer 25/12/10). Aus den Proben wurden die CPCs isoliert, immortalisiert und in flüssigem Stickstoff aufbewahrt. Die Immortalisierung erfolgte durch lentiviralen Gentransfer mit dem Gen für die humane Telomerase Reverse Transkriptase (hTERT).

Für die entsprechenden Versuche wurden Zellen der Zellinie CPC241ht von Christa Bode (AG Orale Biologie und Geweberegeneration der Poliklinik für Zahnärztliche Prothetik, Universitätsmedizin Göttingen) zur Verfügung gestellt. Sie wurden möglichst schnell bei $37^{\circ} \mathrm{C}$ aufgetaut und nach folgender Beschreibung kultiviert.

\subsubsection{Kultivierung der CPCs}

Immortalisierte CPCs wurden in $75 \mathrm{~cm}^{2}$ großen Zellkulturflaschen (\#83.1813.002, Sarstedt, Newton, USA) kultiviert. Das Nährmedium Dulbecco's Modified Eagle's Medium + GlutaMax $(\mathrm{DMEM}+/+)$ in den Zellkulturflaschen wurde alle drei bis vier Tage ausgetauscht. Dadurch stand den Zellen für eine Vermehrung ausreichend Medium zur Verfügung. Vor jedem Wechsel wurden die Zellkulturflaschen unter dem Mikroskop (Carl Zeiss, Göttingen, D) begutachtet und die Ausbreitung der Zellen auf dem Boden beurteilt. So wurde sichergestellt, dass die Zellkulturflaschen nicht zu voll wachsen und eine Differenzierung der Zellen verhindert. 
Kultivierungsmedium DMEM +/+:

500 ml DMEM (\#21885, Gibco, Paisley, UK)

50 ml Fetales Kälberserum FCS (\#10270-106, Gibco, Paisley, UK)

$500 \mu \mathrm{l}$ Gentamycin (\# HN09.1, Roth, Karlsruhe, D)

\subsubsection{Passagieren der CPCs}

Sobald der Boden einer Zellkulturflasche zu etwa $90 \%$ mit Zellen bewachsen war, wurden die CPCs mit Trypsin (PAN Biotech, Aidenbach, D) geerntet. Das Medium wurde verworfen und die Flaschen zweimal mit PBS gewaschen, um Proteinreste des Mediums komplett zu entfernen. Anschließend wurden die Zellen mit $2 \mathrm{ml}$ Trypsin beschichtet und für 4 bis 5 min im Brutschrank inkubiert. Durch leichtes Klopfen gegen die Zellkulturflasche konnten nicht gelöste Zellen mobilisiert werden. Dies wurde unter dem Mikroskop kontrolliert. Die gelösten Zellen wurden in ein 50ml-Falcon-Tube-Röhrchen (Sarstedt, Nümbrecht, D) gegeben. In das Röhrchen wurden 2 ml DMEM +/+ gegeben, um die Trypsin-Aktivität zu beenden. Anschließend erfolgte das zweimalige Ausspülen der Zellkulturflasche mit Medium, um die restlichen Zellen in das Falcon-Tube-Röhrchen zu befördern. Die Zellen wurden durch zehnminütiges Zentrifugieren bei 1200 Umdrehungen pro Minute vom Medium getrennt. Der Überstand wurde entfernt und das Zellpellet in $1 \mathrm{ml}$ PBS resuspendiert. Die Zellzahl wurde anschließend mit einem Zellometer (Cellometer Auto T4 Cell Counter) der Firma Nexcelom Bioscience (Lawrence, USA) bestimmt. Nun konnten neue Zellkulturflaschen mit $7 \times 10^{4}$ Zellen pro Flasche beimpft werden und mit $10 \mathrm{ml}$ Medium versetzt werden. Die übrigen Zellen wurden erneut in PBS resuspendiert und abzentrifugiert. Der Überstand wurde abpipettiert und die Zellpellets bei $-81^{\circ} \mathrm{C}$ eingefroren. Durch die Behandlung mit Trypsin befanden sich die Zellen in den neuen Zellkulturflaschen in der nächsthöheren Passage. 


\subsection{Knockdown von FABP5 mit siRNA}

\subsubsection{Allgemeines zur Methode}

Unter einem Gen-Knockdown (engl. für Herunterregulierung) versteht man eine Minderung der Expression eines Gens in einer Zelle. Folglich kann es zu einer verminderten Synthese des Proteins kommen, für welches das herunterregulierte Gen codiert. So können die Auswirkungen des nur noch wenig bis gar nicht mehr gebildeten Proteins auf die Zelle und schließlich auch auf den gesamten Organismus untersucht werden. Ein solcher Knockdown kann durch Einbringen von Fremd-DNA bzw. -RNA in die Zelle, die sogenannte Transfektion, herbeigeführt werden. In der vorliegenden Arbeit wurde als Fremd-RNA small-interfering RNA (siRNA) verwendet.

Man unterscheidet zwischen der transienten und der stabilen Transfektion. Bei der transienten Transfektion bleibt die Fremd-DNA/-RNA nur für eine kurze Zeit in der Zielzelle. Bei der stabilen Transfektion verbleibt die Fremd-DNA/-RNA über einen längeren Zeitraum in der Zelle, da sie fest in das Genom dieser Zelle eingebaut ist und so vor den Abbauprozessen der Zelle geschützt ist. In der vorliegenden Arbeit wurde letztere Knockdown-Methode verwendet, um die Auswirkungen des Proteins FABP5 auf RUNX2 und SOX9 und damit die Regenerationsprozesse in CPCs zu untersuchen.

Der Knockdown von FABP5 wurde durch die sogenannte Nukleofektion durchgeführt. Dabei macht man sich das Prinzip der Elektroporation zunutze, die es ermöglicht, mittels elektrischer Spannung und bestimmter Reagenzien, Nukleinsäuren in Form von z.B. siRNA in die Zellen und den Zellkern zu befördern. Die Zellmembran der Zielzellen wird durch das Anlegen einer elektrischen Spannung für kurze Zeit für die siRNA permeabel.

\subsubsection{Transfektion der CPCs mit der siRNA}

Die Transfektion wurde mit dem Amaxa Human MSC Nucleofector Kit (Cat. No. VPE1001) der Firma Lonza (Basel, $\mathrm{CH}$ ) durchgeführt. $5 \times 10^{5}$ Zellen wurden mit PBS 
gewaschen und bei $300 \mathrm{~g}$ für $10 \mathrm{~min}$ abzentrifugiert. Für jede Transfektion wurde entsprechend der Herstellerangaben die Transfektionslösung Human MSC Nucleofector Solution hergestellt. Dafür wurden pro Transfektion $90 \mu \mathrm{l}$ Reagenz mit $20 \mu \mathrm{l}$ Supplement gemischt. Das zuvor hergestellte Zellpellet wurde mit $100 \mu \mathrm{l}$ der Transfektionslösung resuspendiert und 0,2 nmol siRNA hinzugegeben. Dieser Ansatz wurde in eine Elektroporationsküvette gegeben und diese in den Nucleofector II von Amaxa Biosystems gestellt. Mit dem Programm U-23 wurden die CPCs einem elektrischen Strom ausgesetzt. Anschließend wurden $500 \mu \mathrm{l}$ Medium in die Küvette gegeben und der gesamte Inhalt tröpfchenweise in eine mit $1 \mathrm{ml}$ Medium befüllte 6Well-Platte gegeben. Nach $24 \mathrm{~h}$ wurde das Medium ausgetauscht und nach einer Inkubation von $48 \mathrm{~h}$ wurden die transfizierten CPCs mithilfe von Trypsin geerntet, in PBS gewaschen und schließlich als Zellpellet bei $-81^{\circ} \mathrm{C}$ eingefroren.

Die verwendete siRNA für den FABP5-Knockdown (Best.-Nr.: SR 301514) wurde bei Origene Technologies (Rockville, USA) bestellt. Es wurden drei verschiedene siRNAProben geschickt. Diese wurden in Vorversuchen getestet und die effektivste siRNA mittels qRT-PCR ausgewählt und in ausreichender Menge bestellt.

Die Effizienz der Transfektion wurde bei jedem Versuch durch eine transiente Transfektion mit GFP (green fluorescence protein) der CPCs kontrolliert. Bei erfolgreicher Transfektion bilden die CPCs das bei UV-Licht-Bestrahlung (Wellenlänge 395 nm) fluoreszierende Protein GFP.

\subsection{Quantitative real-time Polymerase Chain Reaction}

\subsubsection{Allgemeines}

Die quantitative real-time Polymerase Chain Reaction (qRT-PCR) dient der Vervielfältigung bestimmter Nukleinsäuresequenzen. Sie beruht auf dem Prinzip der Polymerase-Kettenreaktion (engl.: polymerase chain reaction) und ermöglicht neben der Vervielfältigung eine Quantifizierung der gewonnenen DNA in Echtzeit. Mit der qRTPCR kann somit der Grad der Genexpression bestimmt werden. 
Für die PCR werden eine hitzestabile Taq-Polymerase und der Fluoreszenzfarbstoff SYBR-Green benötigt. Die Taq-Polymerase muss die bei der PCR auftretenden Temperaturen von $95^{\circ} \mathrm{C}$ überstehen. Während einer PCR werden die folgenden drei Phasen mehrmals durchlaufen:

1. Denaturierung: Durch Erhitzen der DNA auf $95^{\circ} \mathrm{C}$ werden die Doppelstränge in Einzelstränge getrennt.

2. Primer Annealing: Für etwa $30 \mathrm{sec}$ wird die Temperatur soweit reduziert, dass sich die Primer an die DNA-Einzelstränge anlagern.

3. Elongation: Die Taq-Polymerase synthetisiert die Komplementärstränge und es lagert sich der SYBR-Green Fluoreszenzfarbstoff an.

Alle drei Phasen der PCR werden in einem Thermocycler (Mastercycler, Eppendorf, Hamburg, D) durchgeführt und wiederholen sich bis zu 45 mal. Nach jedem Zyklus hat sich die DNA theoretisch verdoppelt. Die Anlagerung des Fluoreszenzfarbstoffs erhöht sich mit jedem Zyklus und die Fluoreszenz wird nach jedem Zyklus vom Thermocycler gemessen. Der Zyklus, in dem die Fluoreszenz einen im PCRProgramm festgelegten Wert überschreitet, wird als ct-Wert (cycle threshold) bezeichnet. Die Menge an eingebautem SYBR-Green in die DNA ist proportional zur Menge der zu Beginn der PCR eingesetzten DNA. Mithilfe des ct-Werts lässt sich also die DNA-Menge des gesuchten Zielgens bestimmen. Je mehr DNA des Zielgens in der Probe vorhanden ist, desto kleiner ist der ct-Wert und umgekehrt. Das heißt, dass die DNA-Menge und der ct-Wert in einem reziproken Zusammenhang stehen. Nach dem letzten Zyklus folgt die Schmelzkurve. Mithilfe der Schmelzkurve lässt sich sicherstellen, dass keine unerwünschten Produkte (Primer-Dimere) entstanden sind und nur die DNA des gesuchten Gens vervielfältigt wurde.

\subsection{2 mRNA-Isolierung aus primären Zellen}

Für die RNA-Isolierung wurde das peqGOLD Total RNA Kit der Firma PEQLAB Biotechnologie (Erlangen, D) verwendet (Order No. 12-6834-02). Die Zellen wurden entweder direkt aus den Zellkulturflaschen entnommen oder, wenn sie bereits bei $-80{ }^{\circ} \mathrm{C}$ eingefroren waren, aufgetaut. Durch Zugabe von $400 \mu \mathrm{l}$ RNA Lysis Buffer T 
zum Zellpellet wurden die Zellen lysiert. Die Lyse konnte direkt in den Zellkulturflaschen durchgeführt werden. Das Lysat wurde anschließend in ein im Kit vorhandenes DNA Removing Column gegeben und dieses Röhrchen auf ein dazu passendes Sammelröhrchen gesteckt. Nach einminütigem Zentrifugieren bei $12.000 \mathrm{~g}$ wurde der Durchfluss mit dem gleichen Volumen 70 \%igen Ethanols versetzt und gemischt. Die gesamte Lösung wurde nun in ein PerfectBind RNA Column gegeben und auf passende Sammelröhrchen gesteckt. Nach dem Zentrifugieren für 1 min bei 10.000 $g$ wurde der Durchfluss verworfen. Danach folgte das Waschen mit $500 \mu \mathrm{l}$ RNA Wash Buffer I und anschließend zweimaliges Waschen mit $600 \mu$ RNA Wash Buffer II. Zwischen den Waschschritten wurden die Proben jeweils für $30 \mathrm{sec}$ bei $10.000 \mathrm{~g}$ abzentrifugiert und der Durchfluss weggeschüttet. Nun wurde die Probe für 2 min bei $10.000 \mathrm{~g}$ trockenzentrifugiert. Im letzten Schritt konnte die gewonnene RNA mit $30 \mu \mathrm{l}$ RNase-freiem Wasser aus dem PerfectBind RNA Column gespült werden. Das Column wurde auf ein Biopur 1,5 ml Eppendorfcup gegeben und für $1 \mathrm{~min}$ bei $5.000 \mathrm{~g}$ abzentrifugiert. Mithilfe des Nanodrop 1000 Spectrometers (PeqLab Biotechnologie $\mathrm{GmbH}$, Erlangen, D) konnte die Konzentration der gewonnenen mRNA (messanger RNA) bestimmt werden.

\subsubsection{Umschreiben von mRNA in cDNA}

Um die Genexpression zu bestimmen, musste die mRNA in cDNA (copy DNA) umgeschrieben werden. Dies wurde mithilfe des QuantiTect Reverse Transcription Kits (Cat.No. 205313) von Qiagen (Venlo, NL) durchgeführt. Das gesamte Umschreiben wurde auf Eis durchgeführt, um eine Degradierung der mRNA zu verhindern. Als erstes erfolgte die Inkubation der mRNA mit genomic DNA wipeout buffer bei $42{ }^{\circ} \mathrm{C}$ für 2 min. Die im Puffer enhaltenen DNasen elimierten die möglicherweise vorhandene restliche genomische DNA. Anschließend wurde die mRNA mit einem Mastermix, bestehend aus Transkriptionspuffer, reverser Transkriptase und Primermix gemischt und für 15 min bei $42{ }^{\circ} \mathrm{C}$ inkubiert. In dieser Zeit wurde die mRNA in cDNA umgeschrieben. Durch Erhitzen der Probe auf $95^{\circ} \mathrm{C}$ für 3 min wurden die Stränge voneinander gelöst, die reverse Transkriptase inaktiviert und der Vorgang somit gestoppt. Anschließend wurde eine Konzentration der cDNA von $1 \mathrm{ng} / \mu \mathrm{l}$ durch Zugabe von 
RNase-freiem Wasser eingestellt. Dabei wurde angenommen, dass das Umschreiben im Verhältnis 1:1 geschah.

\subsection{4 qRT-PCR-Protokoll}

Für die qRT-PCR stand das HotStar Taq DNA Polymerase Kit der Firma Qiagen zu Verfügung. Zu Beginn wurde ein Mastermix wie in Tabelle 2 pipettiert. Es wurde immer ein Ansatz mehr hergestellt, um mögliche Pipettierfehler auszugleichen. Die verwendete 96-Well-Platte (Biozym Scientific GmbH, Hessisch Oldendorf, D) wurde mit einer Microseal B Adhesive Folie (Biozym Scientific GmbH, Hessisch Oldendorf, D) beklebt und die für die PCR benötigten Wells freigeschnitten. Pro Well wurden $9 \mu \mathrm{l}$ Mastermix und $1 \mu \mathrm{l}$ der zu untersuchenden cDNA zusammen pipettiert.

Die befüllten Wells wurden mit Optical Flap Caps (Biozym Scientific GmbH, Hessisch Oldendorf, D) verschlossen und anschließend kurz zentrifugiert. Die Well-Platte wurde in den Thermocycler gestellt, das qRT-Protokoll nach Tabelle 3 eingestellt und die PCR gestartet.

Die PCR wurde dreimal mit dreifachen Ansätzen durchgeführt und es wurde cDNA aus drei verschiedenen Transfektionen verwendet $(n=3)$.

Tabelle 2: PCR Mastermix

\begin{tabular}{ll}
\hline Mastermix pro Well & Menge in $\mu \mathrm{l}$ \\
\hline SYBR-Green & 5 \\
Primermix (forward/reverse) & 2 \\
RNase-freies Wasser & 2 \\
\hline Totalvolumen & 9 \\
\hline
\end{tabular}


Tabelle 3: qRT-PCR-Protokoll

\begin{tabular}{llll}
\hline Phase & Temperatur & Zeit & Zyklen \\
\hline Initiale Aktivierung & $95^{\circ} \mathrm{C}$ & $5 \mathrm{~min}$ & \\
\hline Denaturierung & $95{ }^{\circ} \mathrm{C}$ & $15 \mathrm{sec}$ & \\
Annealing & Je nach Primer & $15 \mathrm{sec}$ & 45 \\
Elongation & $72{ }^{\circ} \mathrm{C}$ & $20 \mathrm{sec}$ & \\
\hline Finale Extension & $72{ }^{\circ} \mathrm{C}$ & $10 \mathrm{~min}$ & \\
\hline Schmelzkurve & Ann. Temp. des Primers $-1^{\circ} \mathrm{C}$ bis $95^{\circ} \mathrm{C}$ & $15 \mathrm{sec}$ & je $8 \mathrm{sec}$ \\
& in $0,2^{\circ} \mathrm{C}$ Schritten & & \\
\hline
\end{tabular}

\subsubsection{Primerdesign}

Der Primer für FABP5 wurde mithilfe der Software primer3 und Primer-BLAST (http://ncbi.nlm.nih.gov) designed. Die Einstellungen von primer3 wurden so gewählt, dass die Primersequenz eine Länge von 18 bis 23 Basenpaare nicht überschritt und einen Guanin- und Cytosingehalt von $40 \%$ und $60 \%$ betrug. Mit Primer-BLAST wurde die designte Primersequenz überprüft, um alternative PCR-Produkte ausschließen zu können.

Die spezifische Sequenz wurde bei der Firma Eurofins Genomics (Ebersberg, D) bestellt und salzfrei sowie lyophilisiert geliefert. Die Primer wurden entsprechend der Herstellerangaben mit RNase-freiem Wasser resuspendiert und bei $-21{ }^{\circ} \mathrm{C}$ aufbewahrt.

Die Primer für die Kollagen-Typ 1, SOX9, RUNX2 und B2M waren bereits vorhanden. Deren Sequenzen sind der Tabelle 6 zu entnehmen.

\subsubsection{Gradienten-PCR}

Zur Bestimmung der Annealing-Temperatur für den Primer FABP5 wurde eine Gradienten-PCR durchgeführt. Dabei wurden 12 Wells einer Wellplatte mit dem jeweils gleichen Ansatz (Tabelle 4) beladen und mit unterschiedlichen Annealing- 
Temperaturen beheizt. Die Temperaturen lagen bei $52^{\circ} \mathrm{C}, 52,2^{\circ} \mathrm{C}, 53,1^{\circ} \mathrm{C}, 54,6^{\circ} \mathrm{C}$, $56,4^{\circ} \mathrm{C}, 58,5^{\circ} \mathrm{C}, 60,7^{\circ} \mathrm{C}, 62,9^{\circ} \mathrm{C}, 64,9^{\circ} \mathrm{C}, 66,6^{\circ} \mathrm{C}, 67,8^{\circ} \mathrm{C}$ und $68,5^{\circ} \mathrm{C}$.

Tabelle 4: Gradienten-PCR: Pipettierschema

\begin{tabular}{ll}
\hline Ansatz pro Well & Menge in $\mu l$ \\
\hline SYBR-Green & 10 \\
Primermix (forward/reverse) & 4 \\
RNase-freies Wasser & 4 \\
CDNA & 2 \\
\hline Totalvolumen & 20 \\
\hline
\end{tabular}

Die Gradienten-PCR wurde mit dem Thermocycler der Firma Eppendorf (Hamburg, D) nach dem Protokoll in Tabelle 5 durchgeführt.

Anhand der entstandenen Schmelzkurve konnte die Annealing-Temperatur bestimmt werden. Hierbei wurde die Temperatur mit der höchsten Extinktion, also die Temperatur, die den höchsten Ausschlag in der Schmelzkurve zeigte, ausgewählt. Um die Spezifität des Primers zu bestätigen, wurde der Primer zusammen mit dem PCRProdukt zu der Firma Sequence Laboratories in Göttingen geschickt. Das Ergebnis der Sequenzierung konnte mit Primer-BLAST (http://ncbi.nlm.nih.gov) überprüft werden.

Tabelle 5: Gradienten-PCR-Protokoll

\begin{tabular}{llll}
\hline Phase & Temperatur & Zeit & Zyklen \\
\hline Initiale Aktivierung & $95^{\circ} \mathrm{C}$ & $5 \mathrm{~min}$ & \\
\hline Denaturierung & $95^{\circ} \mathrm{C}$ & $15 \mathrm{sec}$ & \\
Annealing & unterschiedlich & $15 \mathrm{sec}$ & 45 \\
Elongation & $72^{\circ} \mathrm{C}$ & $20 \mathrm{sec}$ & \\
\hline Finale Extension & $72^{\circ} \mathrm{C}$ & $10 \mathrm{~min}$ & \\
\hline Schmelzkurve & Ann. Temp. des Primers $-1^{\circ} \mathrm{C}$ bis $95^{\circ} \mathrm{C}$ & $15 \mathrm{sec}$ & \\
& in $0,2^{\circ} \mathrm{C} \mathrm{Schritten}$ & je $8 \mathrm{sec}$ & \\
\hline
\end{tabular}




\subsubsection{Verwendete Primer}

Tabelle 6: PCR Primer

\begin{tabular}{llll}
\hline Zielgen & $\begin{array}{l}\text { Forward Primer } \\
5^{\prime} \rightarrow 3^{\prime}\end{array}$ & $\begin{array}{l}\text { Reverse Primer } \\
5^{\prime} \rightarrow 3^{\prime}\end{array}$ & $\begin{array}{l}\text { Annealing } \\
\text { Tempereatur }\end{array}$ \\
\hline FABP5 & tgaaggagctaggagtgggaa & tgcaccatctgtaaagttgcag & $60^{\circ} \mathrm{C}$ \\
SOX9 & caggctttgcgatttaagga & ccgttttaaggctcaaggtg & $60^{\circ} \mathrm{C}$ \\
RUNX2 & ttccagaccagcagcactc & cagcgtcaacaccatcatt & $63^{\circ} \mathrm{C}$ \\
B2M & tgctgtctccatgtttgatgtatct & tctctgctccccacctctaa & $61^{\circ} \mathrm{C}$ \\
Kollagen 1 & ttcccccagccacaaagagtc & ttcccccagccacaaagagtc & $61^{\circ} \mathrm{C}$ \\
\hline
\end{tabular}

\subsubsection{Statistik}

Die gewonnenen PCR-Daten wurden nach der $2^{-\Delta \Delta C T}$-Methode (Pfaffl 2001) quantifiziert, normalisiert und die statistische Signifikanz getestet. Hierbei handelt es sich um ein mathematisches Modell zur Datenanalyse, durch das mittels Berechnung relativer Expressionsverhältnisse eine zuverlässige Auswertung der Expressionsergebnisse möglich ist. Für die Normalisierung wurde ein Housekeeping-Gen verwendet, das im Vergleich zu anderen Genen in allen Geweben sowie zeitlich unabhängig exprimiert wird. Außerdem unterliegt es keiner internen oder externen Regulation. Als Referenzgen diente das Housekeeping-Gen $\beta 2$-Mikroglobulin (B2M), da es während aller PCR-Untersuchungen in allen DNA-Proben konstant exprimiert wurde. Anhand der Expression dieses Housekeeping-Gens kann die Expression der zu untersuchenden Zielgene normalisiert werden. Die Ergebnisse der Normalisierung entsprechen den $\triangle C T$-Werten. In einem weiteren Schritt wurde die relative Expression des Gens in den zu untersuchenden Proben auf Kontrollproben (unbehandelte CPCs) bezogen. Durch den Vergleich der relativen Expression des Zielgens mit der relativen Expression des Kontroll- bzw. Referenzgens lässt sich der $\Delta \Delta \mathrm{CT}$-Wert ermitteln. Durch die Anwendung der arithmetischen Formel $2^{-\triangle \triangle C T}$ lassen sich schließlich die Expressionsunterschiede ermitteln. Das Signifikanzniveau der $\triangle \triangle C T$-Werte lag bei $p<0,05$. Die PCR-Untersuchungen wurden jeweils dreimal wiederholt, um die Reliabilität der Er- 
gebnisse garantieren zu können. Für die Auswertung der Ergebnisse wurde die Software RESTC der Firma Qiagen verwendet (Pfaffl et al. 2002).

\subsection{Western Blot}

\subsubsection{Allgemeines}

Mithilfe des Western Blots, auch bekannt als Immunoblot, lassen sich bestimmte Proteine in einem Proteingemisch gezielt nachweisen. Bevor der Western Blot durchgeführt werden kann, müssen die Proteine nach Ladung und Größe aufgetrennt werden. Dies geschieht durch eine Gelelektrophorese. Bei dieser Methode wandern die Proteine in einem Polyacrylamid-Gel durch ein elektrisches Feld. Aufgrund ihrer Ladung bewegen sich die Proteine in Richtung der Anode und es entstehen Proteinbanden.

Es folgt nun der eigentliche Western Blot. Die Proteine werden vom PolyacrylamidGel auf eine Polyvinylidenfluorid- (PVDF-) Membran übertragen. Hierbei wird das Polyacrylamid-Gel direkt auf die PVDF-Membran gelegt und die Proteine wieder einem senkrecht zur Membran gerichteten elektrischen Feld ausgesetzt. In der mit Transferpuffer gefültten Kammer wandern die Proteine auch hier wieder zur Anode und bleiben wegen hydrophober und polarer Wechselwirkungen auf der PVDF-Membran haften. Die nachzuweisenden Proteine können nun mit AKs nachgewiesen werden. Ein primärer AK haftet an einem bestimmten Protein. Ein sekundärer AK erkennt den primären AK und ist an ein Enzym gekoppelt, welches das anschließend zugegebene Substrat umwandelt und dieses schließlich fluoresziert. Dieses Substrat lässt sich wiederum auf Fotopapier in der Dunkelkammer nachweisen.

\subsubsection{Proteinprobenvorbereitung}

Für die Herstellung des Proteingemischs wurden die zuvor eingefrorenen Zellpellets bei Raumtemperatur für 10 min aufgetaut. Die Zellpellets wurden, wie in 2.2.3 beschrieben, aus den Zellkulturen gewonnen und bei $-81^{\circ} \mathrm{C}$ eingefroren. Vor der Gelelektrophorese wurden die Zellpellets mit einem Probenpuffer resuspendiert. Dieser 
Probenpuffer wurde durch Mischen von $900 \mu \mathrm{l}$ 3x SDS-Probenpuffer mit $100 \mu \mathrm{l} \beta$ Mercaptoethanol (Sigma-Aldrich, Steinheim, D) hergestellt. Pro $1 \times 10^{5}$ Zellen wurden $10 \mu \mathrm{l}$ Probenpuffer zu dem Zellpellet gegeben, resuspendiert und für 5 min bei $95^{\circ} \mathrm{C}$ in einem Heizblock (Thermocycler comfort, Eppendorf, Hamburg, D) erhitzt, um die Proteine zu denaturieren.

$\begin{array}{lll}3 \times \text { SDS-Probenpuffer: } & 3,6 \mathrm{~g} \quad 0,3 \mathrm{M} \text { Tris (Roth, Karlsruhe, D) } \\ & 9 \mathrm{~g} \quad 9 \% \text { SDS (Roth, Karlsruhe, D) } \\ & 22,5 \mathrm{~g} \quad 22,5 \% \text { Glycerin (Roth, Karlsruhe, D) } \\ & \text { Spatelspitze Bromphenolblau } \\ & \text { vor SDS-Zugabe auf } 100 \mathrm{ml} \text { mit Aqua dest. auffüllen, } \\ & \text { pH 6,7 einstellen }\end{array}$

\subsubsection{Natriumdodecylsulfat-Polyacrylamidgelelektrophorese}

Vor der Herstellung des Polyacrylamid-Gels mussten die beiden Glasplatten mit 100 \% Ethanol gereinigt werden, um mögliche Gelreste und andere Verschmutzungen zu beseitigen. Anschließend wurde eine Gummidichtung auf die Glasplatte mit den Spacern gelegt und die Gegenplatte darauf mit Klammern befestigt. Durch Befüllen der Kammer mit Aqua dest. wurde die Dichtigkeit überprüft. In einem Abstand von $6 \mathrm{~cm}$ vom unteren Rand der Glasplatten wurde mit einem Permanentmarker eine Markierung angebracht, die später die Trennlinie zwischen Trenngel und Sammelgel darstellen würde. Nun wurde das Trenngel entsprechend untenstehender Tabelle 7 hergestellt. Entsprechend der Größe der zu untersuchenden Proteine wurde die Porengröße des Trenngels durch Zugabe unterschiedlicher Konzentrationen von Acrylamid variiert. Die Polymerisation des Gels wurde durch Zugabe von AmoniumPeroxodisulfat (APS) (Roth, Karlsruhe, D) gestartet. Anschließend wurde das Trenngel zwischen die beiden Glasplatten bis zur oben genannten Markierung gegossen. Um Luftblasen zu verhindern, wurde eine dünne Schicht 100 \% Ethanol (AppliChem, Darmstadt, D) auf das Trenngel gegeben. Während das Trenngel auspolymerisierte, wurde das Sammelgel, nach untenstehendem Protokoll in Tabelle 8, hergestellt. Auch beim Sammelgel wurde die Polymerisation durch Zugabe von APS eingeleitet. 
Nach Abschütten des Ethanols wurde das Sammelgel auf das nun auspolymerisierte Trenngel zwischen die beiden Glasplatten appliziert. Direkt im Anschluss wurden mithilfe eines Kamms die Probentaschen für das Proteingemisch in das Sammelgel geformt. Nach vollständiger Auspolymerisation wurden Kamm, Klammern und der Dichtungsgummi entfernt.

Mit dem Nachbau einer Biometra Elektrophoresekammer wurde nun die Gelelektrophorese durchgeführt. Hierfür wurden die Kammern mit 1x Laufpuffer befült und die Glasplatten mit dem Gel aufgesetzt und mit Klammern befestigt. Anschließend wurden die vorbereiteten Proteinproben und eine Proteinleiter (Fermentas, \#SM0671) in die Taschen gegeben. Mit dieser Proteinleiter konnte später das genaue Molekulargewicht der aufgetrennten Proteine abgelesen und bestimmt werden. Das aufgetragene Volumen pro Tasche betrug $25 \mu \mathrm{l}$, das Volumen der Proteinleiter standardgemäß $4 \mu$ l. Die Proteinproben wurden bei einer Stromstärke von 10 bis 15 mA im Sammelgel bis zum Erreichen der Trenngelgrenze konzentriert. Anschließend wurden die Proben bei 20 bis 25 mA im Trenngel aufgetrennt. Kurz vor Erreichen des Trenngelendes wurde die Gelelektrophorese gestoppt.

Tabelle 7: Zusammensetzung Trenngel (10 \%)

\begin{tabular}{ll}
\hline & Trenngel $10 \%$ \\
\hline Trenngelpuffer & $1,4 \mathrm{ml}$ \\
$10 \%$ SDS & $55 \mu l$ \\
TEMED & $5 \mu l$ \\
Acrylamid & $1,85 \mathrm{ml}$ \\
$\mathrm{H}_{2} \mathrm{O}$ & $2,0 \mathrm{ml}$ \\
$10 \%$ APS & $0,25 \mathrm{ml}$ \\
\hline
\end{tabular}


Tabelle 8: Zusammensetzung Sammelgel

Sammelgel $5 \%$

Sammelgelpuffer $\quad 1,25 \mathrm{ml}$

$10 \%$ SDS $\quad 50 \mu \mathrm{l}$

TEMED $\quad 5 \mu \mathrm{l}$

Acrylamid $\quad 0,8 \mathrm{ml}$

$\mathrm{H}_{2} \mathrm{O} \quad 2,7 \mathrm{ml}$

$10 \%$ APS $\quad 0,2 \mathrm{ml}$

Sammelgel-Puffer: $15,1 \mathrm{~g}$ Tris $(0,25 \mathrm{M})$

$150 \mathrm{ml}$ Aqua dest.

mit $\mathrm{HCl}$ auf $\mathrm{pH} 6,8$ einstellen

Trenngel-Puffer: $\quad$ 45,4 g Tris (1,5 M)

$250 \mathrm{ml}$ Aqua dest.

mit $\mathrm{HCl}$ auf $\mathrm{pH} 8,9$ einstellen

5x SDS Laufpuffer: $30,3 \mathrm{~g}$ Tris (0,25 M)

142,6 g Glycin (1,9 M)

0,5\% SDS (50 $\mathrm{ml} 10 \% \mathrm{SDS}$ )

mit Aqua dest. auf $1000 \mathrm{ml}$ auffüllen

\subsubsection{Der Western Blot}

Vor Beginn des Blots wurden pro Blot sechs Filterpapiere und eine PVDF-Membran auf die Größe des Trenngels $(9 \mathrm{~cm} \times 6 \mathrm{~cm})$ zurechtgeschnitten. Die PVDF-Membran wurde für $15 \mathrm{sec}$ in 100 \% Methanol aktiviert. Die Filterpapiere, die PVDF-Membran und zwei Schwämme wurden für 15 min in kaltem Transferpuffer eingelegt. Der Zusammenbau der Blotkassette (PeqLab Biotechnologie GmbH, Erlangen, D) erfolgte ebenfalls in kaltem Transferpuffer. So konnte ein möglichst luftblasenfreier Aufbau der Kassette ermöglicht werden. Auf die Anodenseite wurde ein Schwamm, dann drei 
Filterpapiere und schließlich die PVDF-Membran (Milipore, Darmstadt, D) gelegt. Das Trenngel wurde vorsichtig und möglichst luftblasenfrei auf die PVDF-Membran abgelegt und mit drei Filterpapieren und einem weiteren Schwamm bedeckt. Die Blotkassette wurde nun geschlossen und mit zwei Gummibändern fixiert. Anschließend wurde die Blotkassette in den mit kaltem Transferpuffer befüllten Tank gestellt. Die integrierte Wasserkühlung sorgte für eine konstant kalte Temperatur im Tank. Bei einer Stromstärke von 350 mA für 120 min wanderten die Proteine vom Trenngel Richtung Anode auf die PVDF-Membran.

Transfer-Puffer: $\quad 6,05 \mathrm{~g}$ Tris $(25 \mathrm{mM})$ 28,8 g Glycin (192 mM) $400 \mathrm{ml}$ Methanol (20\%) mit Aqua dest. auf 2 Liter auffüllen, pH 8,3

\subsubsection{Proteindetektion}

Um die Proteinbanden sichtbar zu machen, wurde die PVDF-Membran mit Coomassie Brilliant-Blau-Färbung (Roth, Karlsruhe, D) blau angefärbt. Die Färbung wurde in einer kleinen Schale auf dem Schwenktisch durchgeführt, bis die Proteinbanden zu sehen waren. Anschließend wurde die PVDF-Membran mit Entfärberlösung, bestehend aus Methanol und Essigsäure, behandelt und so der Hintergrund entfärbt. Nun konnte die Membran zur Dokumentation eingescannt werden. Daraufhin wurde die Membran für $2 \times 5$ min in TBS-T gewaschen, um Rückstände von Methanol und Essigsäure zu entfernen.

Färbelösung: $\quad$ 0,1 g Brilliant-Blau R $250(0,1 \%)$

$50 \mathrm{ml}$ Methanol (50 \%)

$70 \mathrm{ml}$ Essigsäure (7 \%)

mit Aqua dest. auf $100 \mathrm{ml}$ auffüllen

Entfärberlösung: $\quad 50 \mathrm{ml}$ Methanol (50 \%)

$7 \mathrm{ml}$ Essigsäure (7\%)

mit Aqua dest. auf $100 \mathrm{ml}$ auffüllen 


\subsubsection{Immunmarkierung}

Um unspezifische Bindungen der primäre AKs zu verhindern, wurde die Membran für $1 \mathrm{~h}$ bei Raumtemperatur in $5 \%$ Blocklösung behandelt und somit freie Proteinbindungsstellen geblockt. Die Blocklösung wurde stets frisch angesetzt und bestand aus 5 \% Milchpulver (Roth, Karlsruhe, D) gelöst in TBS-T. Die primären AKs wurden in der oben beschriebenen Blocklösung gemäß der Herstellerangaben oder vorher durchgeführter Verdünnungsreihen verdünnt und auf die Membran gegeben. Die Inkubation wurde bei $4{ }^{\circ} \mathrm{C}$ über Nacht auf einer Wippe durchgeführt. Am nächsten Tag wurden die AKs von der Membran entfernt. Vor Inkubation mit dem sekundären AK wurde die Membran $5 \times 5$ min mit TBS-T gewaschen. Der HRP- (horseraddish peroxidase-) gekoppelte sekundäre AK wurde ebenfalls mit der Blocklösung verdünnt. Je nach Herkunft des primären AK, also aus welchem Wirt dieser gewonnen worden war, wurde der entsprechende sekundäre AK ausgewählt. Die Herkunft der Primär-AKs ist der Tabelle 9 zu entnehmen, die entsprechenden Sekundär-AKs der Tabelle 10. Nach einer Inkubation von $1 \mathrm{~h}$ bei Raumtemperatur wurde die Membran wieder $5 \times 5$ min in TBS-T gewaschen. Für den Nachweis der Immunreaktion wurde (Amersham ECL Prime Western Blotting Detection Reagent) entweder Western Bright oder das etwas stärker lumineszierende Sirius verwendet. Beide Kits bestanden aus Lösung $A$ und $B$, die im Verhältnis 1:1 gemischt und für 5 min auf die Membran aufgebracht wurden. Durch die Zugabe dieser Lösung konnte, zusammen mit der HRP des Sekundär-AKs, die chemolumineszente Reaktion ausgelöst werden. Die Reaktion musste vor Licht geschützt durchgeführt werden. Im Anschluss wurde die Membran in eine Röntgenkassette luftblasenfrei gelegt. Die folgenden Schritte wurden in einer Dunkelkammer durchgeführt. Es wurde ein Amersham Hyperfilm ECL Fotopapier (GE Healthcare, Buckinghamshire, UK) auf die Membran in die Röntgenkassette gelegt und für $1 \mathrm{sec}$ bis mehrere Minuten belichtet. Die Belichtungszeit richtete sich nach dem Proteingehalt auf der Membran. Anschließend wurde der Film für etwa 1 min im Entwickler (Kodak, Rochester, USA) entwickelt. Nach dem Waschen des Films in Leitungswasser wurde dieser im Fixierer (Kodak, Rochester, USA) für 5 min fixiert. Nach erneutem Waschen in Leitungswasser wurde der nun fertige Film getrocknet und eingescannt. Anhand der Höhe der Proteinbande mithilfe 
der Proteinleiter konnte das Molekulargewicht des gesuchten Proteins abgelesen und ausgewertet werden. Außerdem war ein quantitativer Vergleich der verschiedenen Blots möglich.

Blocklösung (5 \% Milch): 2,5 g Milchpulver (A0830,0500, Darmstadt, D) $100 \mathrm{ml} 1 \times$ TBS-T

\subsubsection{Verwendete Antikörper}

Tabelle 9: Western Blot: Verwendete Primärantikörper

\begin{tabular}{|c|c|c|c|}
\hline Name & Firma / Nummer & Herkunft & Verdünnung \\
\hline FABP5 & $\begin{array}{l}\text { Origene, } \\
\text { TA590083 }\end{array}$ & $\begin{array}{l}\text { Kaninchen, IgG, } \\
\text { polyklonal }\end{array}$ & $1: 5.000$ \\
\hline Sox 9 & $\begin{array}{l}\text { Acris, } \\
\text { AP06583PU-N }\end{array}$ & $\begin{array}{l}\text { Kaninchen, } \\
\text { polyklonal }\end{array}$ & $1: 1.000$ \\
\hline Runx 2 (C-12) & $\begin{array}{l}\text { Santa Cruz, } \\
\text { sc-390715 }\end{array}$ & $\begin{array}{l}\text { Maus, } \\
\text { monoklonal }\end{array}$ & $1: 1.000$ \\
\hline alpha-Tubulin & $\begin{array}{l}\text { Sigma-Aldrich } \\
\text { T } 6199\end{array}$ & $\begin{array}{l}\text { Maus, IgG, } \\
\text { monoklonal }\end{array}$ & $1: 1.000$ \\
\hline Kollagen-Typ 1 & $\begin{array}{l}\text { Acris } \\
\text { A120083H }\end{array}$ & $\begin{array}{l}\text { Kaninchen, } \\
\text { polyklonal }\end{array}$ & 1:1000 \\
\hline
\end{tabular}

Tabelle 10: Western Blot: Verwendete Sekundärantikörper

\begin{tabular}{llll}
\hline Name & Firma / Nummer & Herkunft & Verdünnung \\
& & & \\
\hline Anti-Mouse, IgG & Sigma-Aldrich, & Ziege, Anti-Maus, & $1: 40.000$ \\
& A 9917 & Peroxidase gekoppelt & \\
Anti-Rabbit, IgG & Sigma-Aldrich, & Ziege, Anti-Kaninchen, & $1: 100.000$ \\
& A 0545 & Peroxidase gekoppelt & \\
\hline
\end{tabular}




\subsubsection{Auswertung der Western Blots}

Die Dichte und Größe der Proteinbanden auf den eingescannten Röntgenfilmen wurde mit dem Bildbearbeitungsprogramm ImageJ gemessen. Zur Normalisierung wurde der Quotient aus Zielprotein und Ladungskontrolle (a-Tubulin) gebildet (relative Dichte). Durch die Bildung des Quotienten aus relativer Dichte der Probe und der Kontrolle konnte das relative Proteinlevel der Bande berechnet werden. Die Signifikanz der Werte wurde mithilfe des Statistikprogramms Statistica berechnet.

\subsubsection{Strippen der PVDF-Membran}

Um die PVDF-Membran mehrmals verwenden zu können oder zur Aufbewahrung wurde diese für $15 \mathrm{~min}$ in Stripping-Puffer bei $60^{\circ} \mathrm{C}$ gewaschen. Anschließend wurde die Membran $2 \times 10$ min mit TBS-T gewaschen. Die Membran konnte nun für eine weitere Immunmarkierung (siehe 2.5.6) genutzt werden. Für die Aufbewahrung wurde die Membran in $100 \%$ Methanol gewaschen, getrocknet und bei $-20^{\circ} \mathrm{C}$ eingefroren.

Stripping-Puffer: $\quad 62,5 \mathrm{mM}$ Tris-HCl, 2\% SDS, $150 \mathrm{mM}$ 2-Mercaptoethanol $\mathrm{pH} 6,7$ 


\section{Ergebnisse}

\subsection{Immunhistochemischer Nachweis von FABP5}

In Abbildung 5 ist die Lokalisation von FABP5 innerhalb des defekten Knorpels und des anschließenden Knochens dargestellt. FABP5 konnte im Knorpel in der oberflächlichen Schicht sowie in der Tidemark nachgewiesen werden und fehlte in der mittleren und tiefen Zone. Im Knochen beschränkte sich die Lokalisation von FABP5 auf das Fettgewebe des Knochenmarks der Spongiosa.

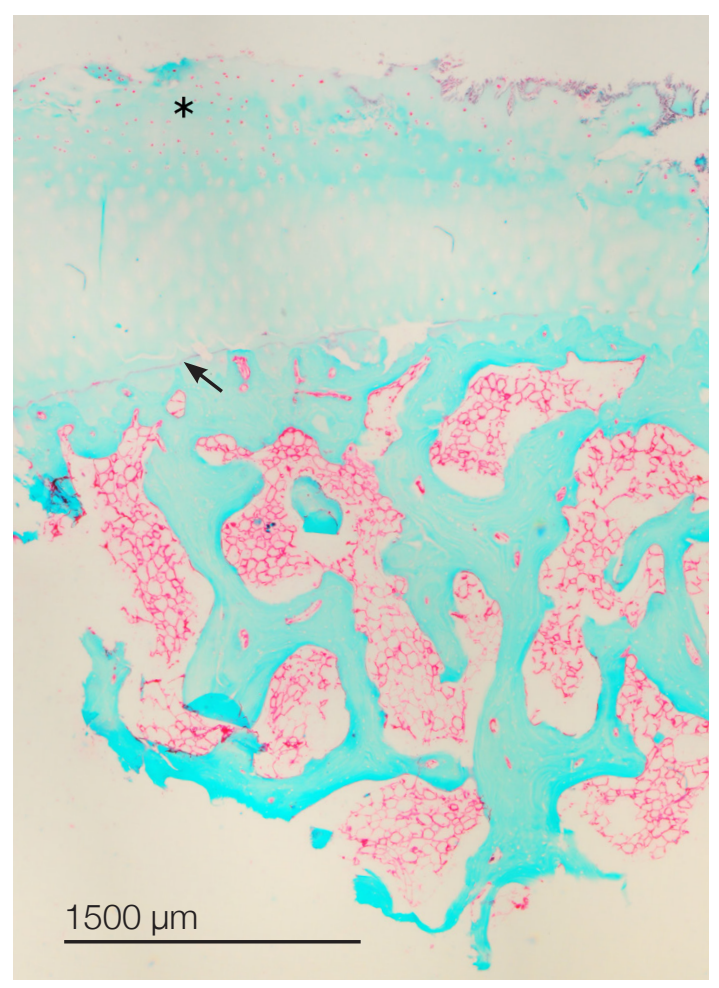

Abbildung 5: Immunhistochemischer Nachweis von FABP5 in erkranktem Knorpel. FABP5 ist in der superfizialen Schicht des Gelenkknorpels und in der Tidemark lokalisiert. Im Knochen ist FABP5 im Fettgewebe des Knochenmarks der Spongiosa lokalisiert. Stern: oberflächliche Schicht, Pfeil: Tidemark. Vergrößerung: 4x. 


\subsection{Knockdown von FABP5 in CPCs}

Zu Beginn wurde der Knockdown von FABP5 untersucht. Als Kontrollgruppe dienten unbehandelte CPCs derselben Passage wie die der transfizierten CPCs. Durch die Fluoreszenz der mit GFP transfizierten CPCs konnte die erfolgreiche Transfektion gezeigt werden (siehe Abbildung 6).
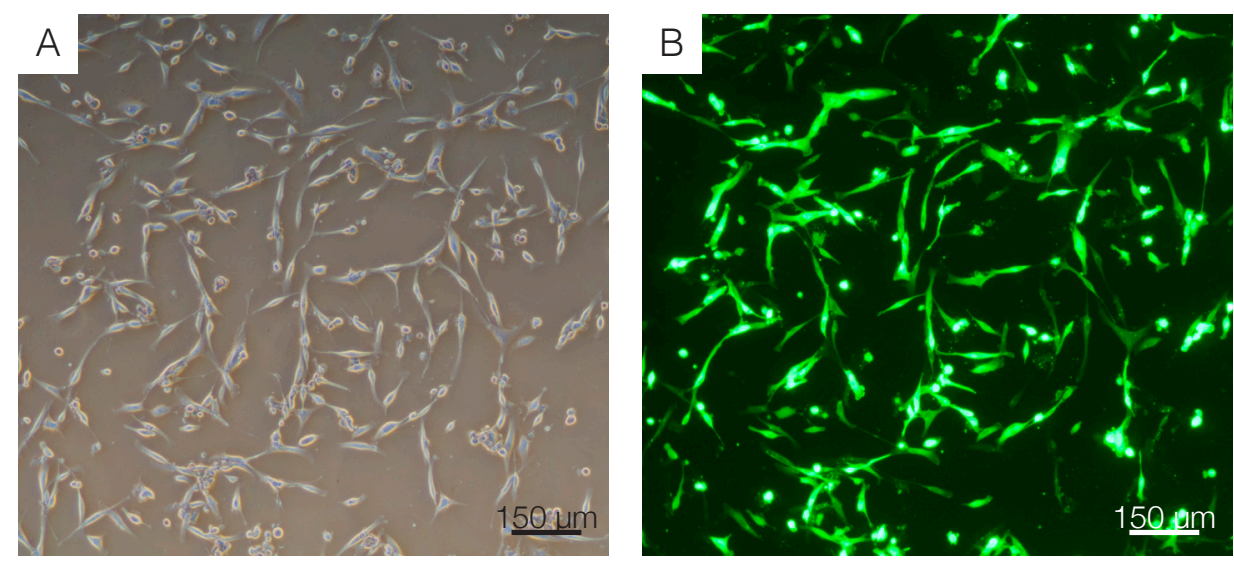

Abbildung 6: Zellkultur chondrogener Progenitorzellen nach der Transfektion mit GFP.

A: Lichtmikroskopische Darstellung der CPCs $48 \mathrm{~h}$ nach der transienten Transfektion mit GFP. B: Fluoreszenzmikroskopische Darstellung der CPCs nach der transienten Transfektion mit GFP. Vergrößerung: 5x.

Um den Knockdown von FABP5 in den CPCs zu untersuchen, wurden die relativen mRNA-Level von FABP5 mithilfe der QRT-PCR sowie das Proteinlevel von FABP5 im Western Blot bestimmt.

Im Western Blot, also auf Proteinebene, konnte der Rückgang der Expression von FABP5 nach der Transfektion der CPCs mit FABP5-siRNA nachgewiesen werden. Die Proteinbande war in den unbehandelten CPCs erheblich stärker als in den CPCs mit FABP5-Knockdown. Die Proteinbanden fanden sich auf der für FABP5 typischen Höhe von 15 kDa. Die Bande war in der Kontrolle deutlich stärker als die Bande der behandelten Probe (Abbildung 7B).

In Abbildung 7A zeigt die Übertragung der Proteine vom Polyacrylamid-Gel auf die 
PVDF-Membran. Die Abbildung zeigt exemplarisch eine Coomassie-Färbung für alle durchgeführten Western Blots.

Das Housekeeping-Gen a-Tubulin diente in allen Western Blots als Ladungskontrolle. So konnte das Proteinlevel zwischen der unbehandelten Kontrolle und den CPCs mit FABP5-Knockdown gegen a-Tubulin normalisiert werden und die Ergebnisse für die quantitative Auswertung der Western Blots verwendet werden.
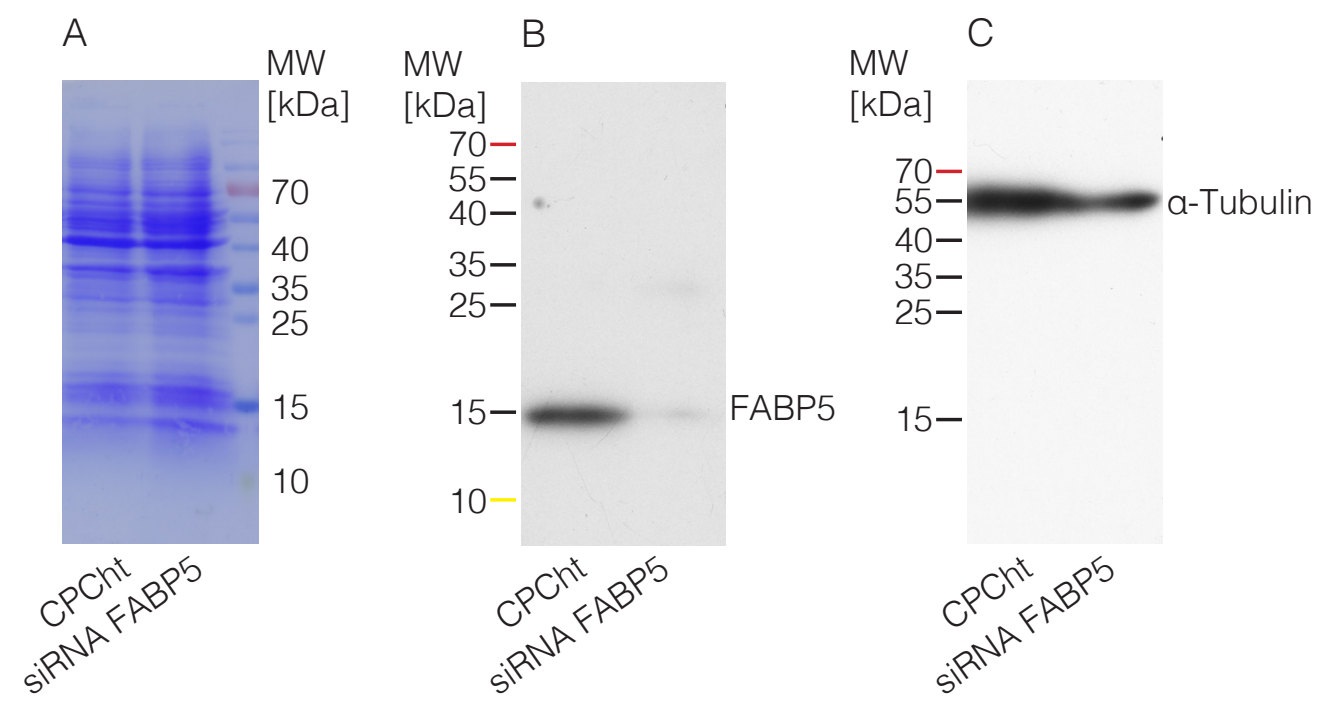

Abbildung 7: Western Blot-Ergebnisse für FABP5 und a-Tubulin. Auf der linken Bande sind jeweils CPCs (CPCht) als Kontrolle aufgetragen, auf der rechten Bande mit FABP5-siRNA transfizierte CPCs (siRNA FABP5). Es wurden pro Spur $25 \mu$ Proteinlysat in $10 \%$-igen Gelen durch SDS-PAGE getrennt. A: Coomassie-Färbung des Western Blots. B: Proteinbande für FABP5 bei dem Molekulargewicht von ca. $15 \mathrm{kDa}$ und bei einer AK-Verdünnung von 1:5000, deutlich höheres Expressionslevel bei den Kontroll-CPCs als bei den transfizierten CPCs. C: Proteinbande für a-Tubulin bei einer AK-Verdünnung 1:5000. Das Housekeeping-Gen aTubulin diente als Ladungskontrolle.

Bei der quantitativen Auswertung der qRT-PCR-Ergebnisse konnte eine deutliche Verringerung des m-RNA-Levels für FABP5 festgestellt werden. Verglichen wurden jeweils die transfizierten CPCs mit den unbehandelten CPCs. Dabei zeigte sich, dass 
nur noch $10 \% \pm 2 \%$ der ursprünglichen Menge an mRNA von FABP5 exprimiert wurde. Die qRT-PCR wurde mit der cDNA aus drei unterschiedlichen Transfektionen durchgeführt. Die Unterschiede zwischen der Kontrolle und den behandelten CPCs waren immer signifikant $(p<0,05)$.

Die Proteinlevel von FABP5 stimmten mit dem Ergebnis der qRT-PCR überein. So zeigten die Western Blot-Ergebnisse, dass die Expression von FABP5 auf Proteinebene auf $8 \% \pm 7 \%$ sank, verglichen mit der Expression in unbehandelten CPCs (Abbildung 8B). Es wurden Western Blots mit CPCs aus drei verschiedenen Transfektionen durchgeführt ( $n=3)$. Der Unterschied zwischen Kontrolle und den transfizierten CPCs war immer signifikant $(p<0,05)$.

A
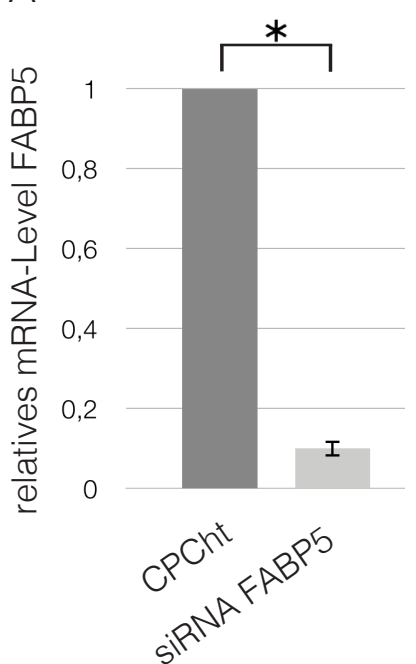

$\mathrm{B}$
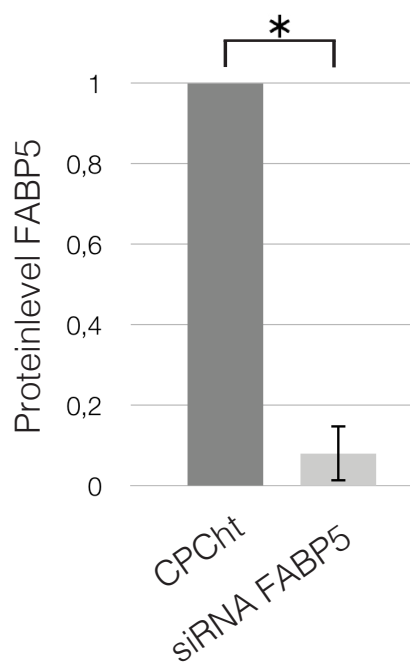

Abbildung 8: Quantitative Auswertung des relativen mRNA-Levels und des Proteinlevels von FABP5 in CPCs vor und nach dem Knockdown von FABP5. A: Relatives mRNA-Level von FABP5 in CPCs mit einem Gen-Knockdown von FABP5 (siRNA FABP5) und in der Kontrolle (CPCht). Es zeigte sich eine deutliche Verringerung des mRNA-Levels für FABP5 in den transfizierten CPCs. B: Die Expression von FAB5 war auch auf Proteinebene verringert. Die Ergebnisse sind Mittelwerte von drei getrennten Experimenten $(n=3)$, die Fehlerbalken beschreiben die Standardabweichung. ${ }^{*}=$ signifikant $(p<0,05)$ 


\subsection{Nachweis von SOX9}

Der Knockdown von FABP5 in den CPCs wirkte sich auf die Expression von SOX9 nicht aus. Das mRNA-Level und Proteinlevel veränderten sich nur wenig. Auffallend war jedoch die hohe Standardabweichung bei den qRT-PCR-Ergebnissen von 0,35. Im Durchschnitt lag die Expression von SOX9-mRNA in den CPCs mit FABP5Knockdown bei 0,98 verglichen mit der Expression in den unbehandelten CPCs (Abbildung 9A).

A
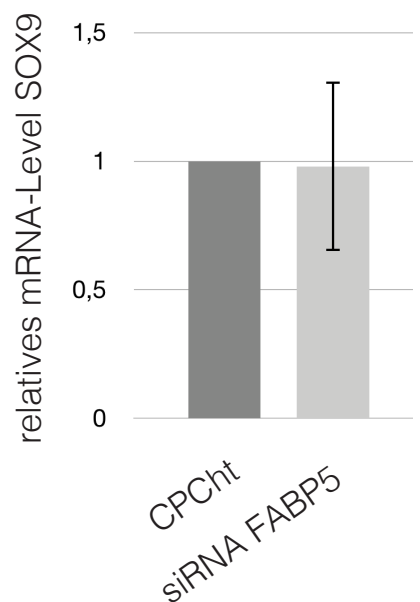

B
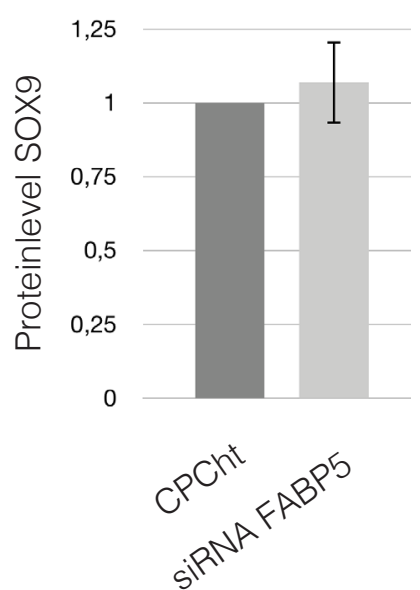

C

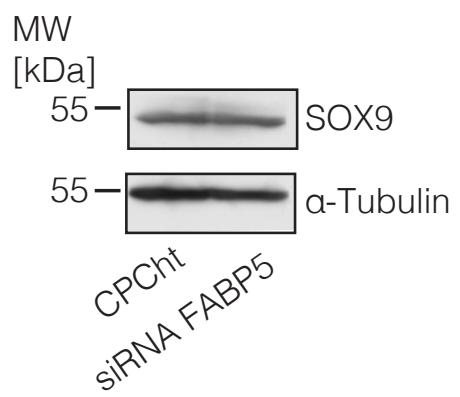

Abbildung 9: Quantitative Auswertung des relativen mRNA-Levels und des Proteinlevels von SOX9 in CPCs vor und nach dem Knockdown von FABP5. A: Das relative mRNA-Level von SOX9 war in den CPCs mit FABP5-Knockdown (siRNA FABP5) sowohl erhöht als auch erniedrigt. Auffallend war die große Standardabweichung von 0,35. B: Das Proteinlevel von SOX9 stimmte mit den Ergebnissen der qRT-PCR überein. Jedoch zeigte sich hier eine geringere Standardabweichung von nur 0,14. Die Expressionslevel von SOX9 in den unbehandelten CPCs (CPCht) und den CPCs mit FABP5-Knockdown (siRNA FABP5) unterschieden sich nur gering. C: Proteinbanden für SOX9 (AK-Verdünnung 1:1000) und a-Tubulin (AKVerdünnung 1:5000). Das Housekeeping-Gen a-Tubulin diente als Ladungskontrolle. A,B: Die Ergebnisse sind Mittelwerte von drei getrennten Experimenten $(n=3)$, die Fehlerbalken beschreiben die Standardabweichung. 
Die Expression des Proteins SOX9 war in den Knockdown-Zellen im Mittel um 7 \% erhöht (Standardabweichung: 0,14). Der Signifikanztest zeigte, dass sich Kontrolle und CPCs mit Knockdown nicht signifikant unterscheiden ( $p>0,85)$ (Abbildung 9B). Im Western Blot waren die Proteinbanden auf der für SOX9 und a-Tubulin typischen Höhe von 55 kDa zu sehen (Abbildung 9C). Die Banden für SOX9 waren in Kontrolle und behandelter Probe gleich stark. Das Housekeeping-Gen a-Tubulin diente in allen Western Blots als Ladungskontrolle. So konnte das Proteinlevel zwischen der unbehandelten Kontrolle und den CPCs mit FABP5-Knockdown gegen a-Tubulin normalisiert werden und die Ergebnisse für die quantitative Auswertung der Western Blots verwendet werden.

Die für die qRT-PCR und die Western Blots verwendeten CPCs entstammten aus drei unterschiedlichen Transfektionen $(n=3)$. 


\subsection{Nachweis von RUNX2}

Der Knockdown von FABP5 reduzierte in den CPCs die Expression von RUNX2. Die quantitative Auswertung der qRT-PCR-Ergebnisse zeigte, dass RUNX2 im Mittel nur noch zu 12 \% in den Knockdown-CPCs verglichen mit unbehandelten CPCs exprimiert wurde (Standardabweichung: 0,06) (Abbildung 10A). Die Unterschiede der RUNX2-Expression zwischen Kontrolle und behandelten CPCs waren signifikant $(p<$ 0,05). Die qRT-PCR wurde mit der cDNA aus drei unterschiedlichen Transfektionen durchgeführt.

Auf Proteinebene war die RUNX2-Expression ebenfalls reduziert. RUNX2 wurde im Mittel nur noch zu 16 \% exprimiert (Standardabweichung: 0,19) (Abbildung 10B).

Die Proteinbande stellte sich im Western Blot bei dem für RUNX2 typischen Molekulargewicht von etwas unter $70 \mathrm{kDa}$ dar. Die Bande ist in der Kontrolle deutlich stärker als in der behandelten Probe (Abbildung 9C).

Das Housekeeping-Gen a-Tubulin diente in allen Western Blots als Ladungskontrolle. So konnte das Proteinlevel zwischen der unbehandelten Kontrolle und den CPCs mit FABP5-Knockdown gegen a-Tubulin normalisiert werden und die Ergebnisse für die quantitative Auswertung der Western Blots verwendet werden (Abbildung 10C).

Es wurden Western Blots mit CPCs aus drei verschiedenen Transfektionen durchgeführt ( $n=3)$. Der Unterschied zwischen Kontrolle und den Knockdown-CPCs war immer signifikant $(p<0,05)$. 
A

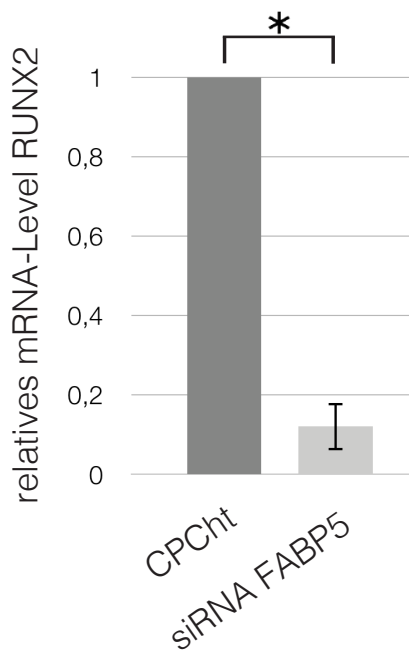

B

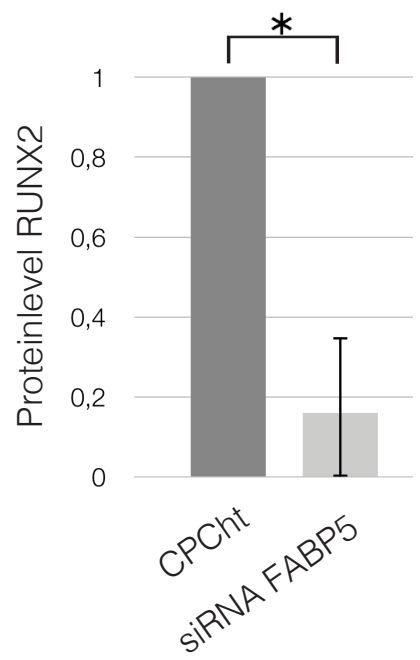

C

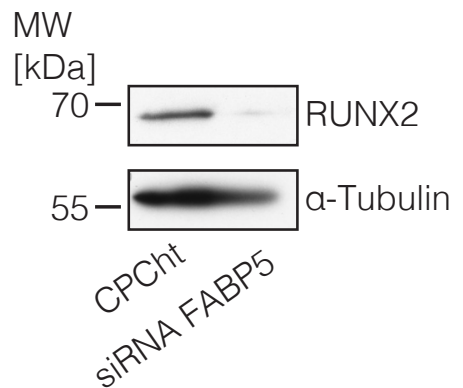

Abbildung 10: Quantitative Auswertung des relativen mRNA-Levels und des Proteinlevels von RUNX2 in CPCs vor und nach dem Knockdown von FABP5. A: Das relative mRNALevel von RUNX2 war in den CPCs mit FABP5-Knockdown (siRNA FABP5) erniedrigt. (CPCht $=$ Kontrolle) B: Das Proteinlevel von RUNX2 war in den CPCs mit FABP5Knockdown (siRNA FABP5) erniedrigt. C: Proteinbanden für RUNX2 (AK-Verdünnung 1:1000) und a-Tubulin (AK-Verdünnung 1:5000). Das Housekeeping-Gen a-Tubulin diente als Ladungskontrolle. A, B: Die Ergebnisse sind Mittelwerte von drei getrennten Experimenten $(n=3)$, die Fehlerbalken beschreiben die Standardabweichung. ${ }^{*}=$ signifikant $(p<0,05)$. 


\subsection{Nachweis von Kollagen-Typ 1}

Der Knockdown von FABP5 bewirkte in den CPCs eine geringere Expression von Kollagen-Typ 1 sowohl auf genetischer Ebene wie auch auf Proteinebene.

So sank die Expression von Kollagen-Typ 1-mRNA im Mittel auf nur noch $13 \%$ in den CPCs mit FABP5-Knockdown im Vergleich zu den Kontroll-CPCs (Standardabweichung: 0,03). Der Unterschied zwischen den beiden Gruppen war signifikant ( $p<$ 0,05) (Abbildung 11A). Die qRT-PCR wurde mit der cDNA aus drei unterschiedlichen Transfektionen durchgeführt.

Die Expression des Proteins Kollagen-Typ 1 war bei den CPCs mit FABP5Knockdown deutlich reduziert. Im Mittel wurde Kollagen-Typ 1 nur noch zu 35 \% exprimiert, eine Abnahme um 65 \% des Ausgangswertes (Standardabweichung: 0,06) (Abbildung 11B).

Die Proteinbanden waren bei dem für Kollagen-Typ 1 typischen Molekulargewicht von 130 kDa zu erkennen. In der Kontrolle war die Bande deutlich stärker als in der behandelten Probe (Abbildung 11C).

Das Housekeeping-Gen a-Tubulin diente in allen Western Blots als Ladungskontrolle. So konnte das Proteinlevel zwischen der unbehandelten Kontrolle und den CPCs mit FABP5-Knockdown gegen a-Tubulin normalisiert werden und die Ergebnisse für die quantitative Auswertung der Western Blots verwendet werden (Abbildung 11C).

Es wurden Western Blots mit CPCs aus drei verschiedenen Transfektionen durchgeführt ( $n=3)$. Der Unterschied zwischen Kontrolle und Knockdown war signifikant ( $\mathrm{c}$ $0,05)$. 
A

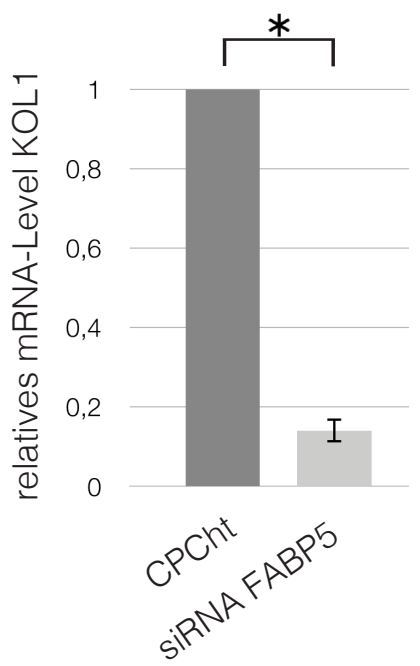

B

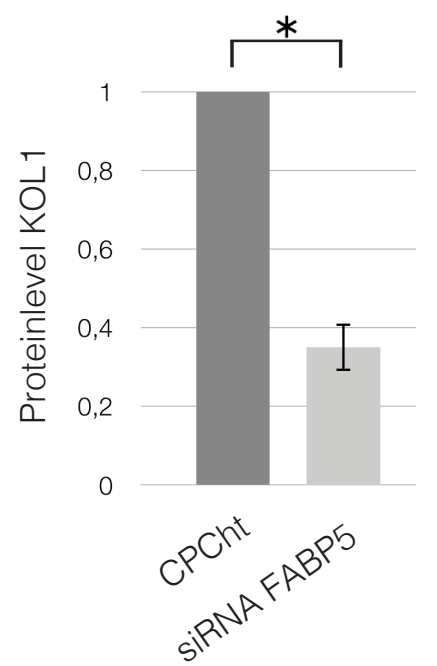

C

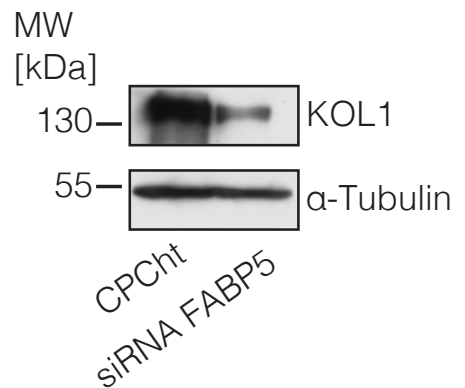

Abbildung 11: Quantitative Auswertung des relativen mRNA-Levels und des Proteinlevels von Kollagen-Typ 1 in CPCs vor und nach dem Knockdown von FABP5. A: Das relative mRNA-Level von Kollagen-Typ 1 war in den CPCs mit FABP5-Knockdown (siRNA FABP5) erniedrigt (CPCht $=$ Kontrolle). B: Das Proteinlevel von Kollagen-Typ 1 war in den CPCs mit FABP5-Knockdown (siRNA FABP5) erniedrigt. C: Proteinbanden für Kollagen-Typ 1 (AKVerdünnung 1:1000) und a-Tubulin (AK-Verdünnung 1:5000). Das Housekeeping-Gen aTubulin diente als Ladungskontrolle. A, B: Die Ergebnisse sind Mittelwerte von drei getrennten Experimenten $(n=3)$, die Fehlerbalken beschreiben die Standardabweichung. ${ }^{*}=$ signifikant $(p<0,05)$. 


\section{Diskussion}

\subsection{Vorkommen von FABP5 in CPCs und Knorpelgewebe}

In den immunhistochemischen Nachweisreaktionen konnte FABP5 im Knorpel und Knochen des Kniegelenks dargestellt werden. Da aus ethischen Gründen lediglich Kniegelenksproben von an OA erkrankten Patienten untersucht werden konnten, war ein direkter Vergleich zwischen erkranktem und gesundem Knorpel nicht möglich. Die erkrankten Kniegelenke konnten hinsichtlich histologischer Unterschiede in gesündere und erkrankte Bereiche eingeteilt werden und diese dann miteinander verglichen werden. Die gesunden Bereiche der Gewebeproben wären somit aber keine echten Kontrollgruppen. Bando et al. (2014) wiesen FABP5 immunhistochemisch in den Wachstumsplatten des Femurs von Mäusen nach. Die angefärbten Zellen waren hier entlang der Tidemark lokalisiert und die positive Färbung erstreckte sich über das Zytoplasma und den Zellkern. Allerdings bezeichnen die Autoren die positiv angefärbten Zellen als Osteoklasten und FABP5 als einen spezifischen Marker für diesen Zelltyp (Bando et al. 2014). Diese Ergebnisse stimmen mit den hier gezeigten Beobachtungen nur zum Teil überein. So war in der vorliegenden Arbeit FABP5 im Gelenkknorpel nicht nur in der Tidemark angefärbt, sondern auch in den noch verbliebenen oberflächlichen Teilen der mittleren Schicht in den späten Stadien der OA.

Im Knochen ist FABP5 deutlich im Fettgewebe des Knochenmarks der Spongiosa angefärbt. FABP5 ist hier insbesondere in den dort ansässigen Fettzellen lokalisiert. Das Knochenmark der Röhrenknochen besteht aus großen Mengen an Fettgewebe. Im Mausmodell konnte FABP5 in Fettzellen in geringen Mengen nachgewiesen werden (Hotamisligil et al. 1996). FABP5 wird außerdem in großen Mengen in differenzierten Makrophagen exprimiert (Storch und Thumser 2010). 


\subsection{Einfluss des FABP5-Knockdowns auf SOX9 und RUNX2}

Die Beeinflussung der Genexpression mittels siRNA ist eine etablierte Methode. Mit ihr lassen sich bedingt Rückschlüsse auf die Funktion eines Proteins ziehen. Das Protein kann herunterreguliert sowie überexprimiert werden. In der vorliegenden Arbeit wurde FABP5 herunterreguliert und die Auswirkungen dieses Knockdowns auf die Expression von SOX9, RUNX2 und Kollagen-Typ 1 auf mRNA-Ebene und Proteinebene untersucht.

In den durchgeführten Versuchen konnte der erfolgreiche Knockdown von FABP5 sowohl auf mRNA-Ebene als auch auf Proteinebene nachgewiesen werden. Die qRT-PCR-Ergebnisse stimmten mit den Western Blot-Ergebnissen überein. Es konnte kein kompletter Knockdown gezeigt werden. Der Knockdown von FABP5 führte in den CPCs zu einer verminderten Expression von RUNX2. Ein Effekt, dass diese „Herunterregulierung“ von RUNX2 die Expression von SOX9 erhöht, konnte nicht gezeigt werden. Bei den hier gezeigten Ergebnissen blieb die Expression von SOX9 nach dem FABP5-Knockdown nahezu gleich. Koelling et al. (2009) zeigten hingegen, dass sich SOX9 und RUNX2 gegenseitig beeinflussen. Hier führte der direkte Knockdown von RUNX2 zu einer Erhöhung der Expression von SOX9 und dies verstärkte das chondrogene Potenzial der CPCs. Bis zur Untersuchung der RUNX2- und SOX9-Expression nach der Transfektion wurden die CPCs 96 h kultiviert (Koelling et al. 2009). Dass sich in den hier gezeigten Ergebnissen die Herunterregulierung von RUNX2 nicht auf die SOX9-Expression auswirkte, könnte an der Wachstumszeit der CPCs nach der Transfektion mit FABP5-siRNA von nur 48 h statt 96 h liegen. Um dies untersuchen zu können, müssten die CPCs mit der stabilen Transfektion behandelt werden. Bei dieser Methode wird die siRNA in das Genom aufgenommen und somit während der Zellteilung weitergegeben.

Koelling et al. (2009) zeigten in adipogen differenzierten CPCs ein erhöhtes Level der Lipoproteinlipase und von PPARy, bei gleichzeitig niedriger Expression von SOX9 und Kollagen-Typ 1. Hihi et al. (2002) stellten fest, dass sich undifferenzierte Fibroblasten mithilfe von PPARy zu Adipozyten differenzieren können. PPARy ist ein liganden-aktivierter Transkriptionsfaktor, dem anfangs nur eine Schlüsselrolle bei der 
Fettgewebshomöostase zugeschrieben wurde. Mittlerweile konnten weitere Funktionen wie eine anti-inflammatorische, eine anti-katabolische und eine antifibrotische Funktion gezeigt werden (Vasheghani et al. 2015). In diversen Studien konnten diese Effekte mit Agonisten von PPARy sowohl in vitro als auch in vivo nachgewiesen werden (Afif et al. 2007; Kapoor et al. 2007). In Tiermodellen schützte beispielsweise die Gabe des PPARy-Agonisten Pioglitazone vor der experimentellen OA (Boileau et al. 2007; Kobayashi et al. 2005). Vasheghani et al. (2015) zeigten, dass das Gelenkknorpelgewebe durch die Inhibition des über PPARy gesteuerten mTOR-Proteins (mammalian target of rapamycin) vor einer experimentellen OA geschützt wird. Dies geschieht zum Teil über die Autophagie-fördernde Funktion von mTOR. Autophagie scheint ein protektiver Mechanismus in gesundem Gelenkknorpel zu sein und der altersbedingte Verlust dieser Funktion wird mit Zelltod und OA assoziiert (Carames et al. 2010). Bis jetzt konnten die genauen Effekte dieser Agonisten von PPARy noch nicht geklärt werden und auch die Rolle, die PPARy in vivo bei der Gelenkknorpelhomöostase spielt, ist noch größtenteils unbekannt (Vasheghani et al. 2015). Ein direkter Zusammenhang zwischen FABP5 und PPARy konnte bisher noch nicht hergestellt werden. Bando et al. (2014) konnten einen Zusammenhang von FABP5 und PPARB/ $\delta$ feststellen. Hier wirken auch die durch FABP5 transportierten Fettsäuren als direkte Liganden von PPARß/ס.

Für FABP4 (auch Adipozyten-FABP), ein naher Verwandter von FABP5, konnte eine direkte Interaktion mit PPARy gezeigt werden (Adida und Spener 2006). FABP4 kommt vorwiegend in Adipozyten, Monozyten und Makrophagen vor. Neben der Regulation des Fettstoffwechsels über die hormonsensitive Lipase hat FABP4 auch Einfluss auf Entzündungsprozesse (Smathers und Petersen 2011). FABP4 wird als ein von Adipozyten und Makrophagen sezerniertes Adipokin (Hormon) angesehen (Kralisch und Fasshauer 2013). Die Interaktion zwischen Adipozyten und Makrophagen führte in vitro zur Sezernierung von FABP4 in das Kulturmedium (Ohira et al. 2013). Außerdem konnten Korrelationen zwischen dem Serumlevel von FABP4 und Adipositas sowie dem metabolischen Syndrom und der Atherosklerose nachgewiesen werden (Kaess et al. 2012; Thumser et al. 2014). Verschiedene Studien zeigten, dass die Hochregulierung von FABPs, speziell von FABP4, Lipolyse in Adipozyten, 
eine Entzündungsantwort der Makrophagen sowie Insulinresistenz induzierten (Furuhashi et al. 2011). Bei der adipogenen Differenzierung von primären Osteoblasten konnte eine erhöhte Expression von FABP4 festgestellt werden (Zhang und Yang 2013). Interessanterweise besteht ein Zusammenhang zwischen FABP5 und FABP4; so war die FABP5-Expression bei FABP4-Knockout-Mäusen hochreguliert, möglicherweise um den Verlust von FABP4 zu kompensieren (Shaughnessy et al. 2000). FABP4 wurde im Zusammenhang mit der OA bisher noch nicht untersucht.

Die Überexpression von SOX9 in osteoarthritischen und normalen Chondrozyten führte zur erhöhten Expression von Kollagen-Typ 2 und Proteoglykanen (Cucchiarini et al. 2007). Chondrogen differenzierte CPCs wiesen eine erhöhte Expression von SOX9 und Kollagen-Typ 2 und niedrige Expression von RUNX2 und Kollagen-Typ 1 auf. Bei den osteogen differenzierten CPCs war diese Expression genau umgekehrt (Koelling et al. 2009). Miosge et al. (2004) konnten zeigen, dass osteoarthritisches Knorpelgewebe reich an Kollagen-Typ 1 ist. Die CPCs dahingehend zu beeinflussen, dass sie durch die erhöhte SOX9-Expression vermehrt Kollagen-Typ 2 bilden, kann als ein therapeutisches Ziel angesehen werden. Der hier gezeigte Rückgang der Kollagen-Typ 1-Expression ist auf die verminderte RUNX2-Expression zurückzuführen und ist ein erster Hinweis darauf, dass der FABP5-Knockdown die CPCs möglicherweise zur Bildung von Kollagen-Typ 2 anregt. Dieser Effekt muss jedoch in Zukunft noch untersucht werden.

Die PPARs könnten als potenzielles Ziel der OA-Therapie angesehen werden. Wie genau nun FABP5 und PPAR miteinander agieren und wie sich dies auf die Expression von RUNX2 und SOX9 auswirkt, muss noch untersucht werden. Dies wirft auch die Frage auf, welche Auswirkungen einzelne Fettsäuren auf RUNX2 haben oder ob die RUNX2-Expression auch direkt durch FABP5 beeinflusst werden kann. So sollte auch untersucht werden, ob der FABP5-Knockdown weniger PPAR-Aktivität bedeutet und sich in Folge dessen das adipogene Differenzierungspotenzial der CPCs reduziert. So könnte möglicherweise der Knockdown von FABP5 über PPAR die adipogene Differenzierung der CPCs verhindern. Die gleichzeitige Reduzierung der 
RUNX2-Expression könnte bedeuten, dass die osteogene Differenzierung der CPCs unterbunden wird.

\subsection{OA und Adipositas}

Wie bereits erwähnt, können die FABPs als Adipokine, also Botenstoffe, angesehen werden. Adipositas ist einer der Hauptrisikofaktoren für die Entstehung einer OA. Dabei sind nicht nur die lasttragenden Hüft-, Knie- und Fuß-Gelenke betroffen, sondern auch Hand- und Fingergelenke (Oliveria et al. 1999) Der Zusammenhang von Übergewicht und $\mathrm{OA}$ in den Gelenken, die kein Gewicht tragen, scheint somit eine weitaus komplexere Ätiologie aufzuweisen. Bis heute ist noch nicht geklärt, wie Übergewicht zur Ausbildung der OA führt (Thijssen et al. 2015). Lange wurde dem Fettgewebe lediglich eine Rolle als Fettspeicher und somit im Energiehaushalt zugeschrieben. Durch die Freisetzung von pro-inflammatorischen Molekülen, Komplementfaktoren, Signalmolekülen, Wachstumsfaktoren und Adhäsionsmolekülen haben die Adipozyten des Fettgewebes jedoch großen Einfluss auf das Entzündungsgeschehen (Ehling et al. 2006). So beschrieben Ushiyama et al. (2003) die Synthese von pro-inflammatorischen Zytokinen und Wachstumsfaktoren im infrapatellaren Fettpolster von Patienten mit einer OA, und Yamasaki et al. (2004) zeigten, dass sich die Fibroblasten unter dem Einfluss von Zytokinen zu Adipozyten differenzieren. Es ist nicht verwunderlich, dass die FABPs eine wesentliche Rolle bei der Entstehung von Adipositas spielen. So sind Polymorphismen in den FABP-Genen mit einer erhöhten Inzidenz von Erkrankungen des durch Adipositas verursachten metabolischen Syndroms und des Insulin-resistenten Diabetes mellitus Typ 2 assoziiert (Thumser et al. 2014). In einer Studie konnte gezeigt werden, dass FABP4 und FABP5 bei übergewichtigen, präpubertären Jungen erhöht sind (Canas et al. 2015). Im Mausmodell führte der Knock-In von FABP5 über das glukoseabhängige insulinotrope Peptid (GIP) zur Entwicklung einer ernährungsbedingten Adipositas (Shibue et al. 2015).

Adiponectin und Leptin sind zwei weitere Vertreter der Adipokine, die an der Entstehung einer OA beteiligt sind. Adiponectin wird bei Übergewicht vermindert gebildet (Challa et al. 2010). Im Gegensatz dazu steigt die Leptin-Ausschüttung mit zuneh- 
mendem Körpergewicht proportional (Considine et al. 1996). Der Adiponectin-Level scheint bei OA-Patienten erniedrigt zu sein (Poonpet und Honsawek 2014), während der Leptin-Level bei einer OA ansteigt (Lubbeke et al. 2013). Adiponectin wirkt dabei pro-inflammatorisch (de Boer et al. 2012) und scheint die Knochenentwicklung positiv zu beeinflussen (Challa et al. 2010). Leptin hat vor allem katabole Effekte auf den Knorpelmetabolismus in osteoarthritischen Gelenken (Poonpet und Honsawek 2014). In einer Dissertations-Arbeit dieser Arbeitsgruppe konnten beide Adipokine in den CPCs nachgewiesen werden. Die Auswirkungen von Adiponectin waren sowohl proals auch anti-inflammatorisch, Leptin wirkte sich hauptsächlich entzündungsfördernd auf die CPCs aus (Johannsen 2015).

\subsection{FABP5 und TGF- $\beta$}

TGF- $\beta$ spielt eine wichtige Rolle bei der Homöostase von Knorpelgewebe. So korreliert ein Mangel an TGF- $\beta$ mit Knorpelgewebsschäden und führt schließlich zu einer OA. Andere Studien belegen, dass TGF- $\beta$ der Wirkung katabolischer Zytokine entgegenwirkt und so eine Knorpeldegeneration überwunden werden kann (Blaney Davidson et al. 2007). Knoferle et al. (2010) konnten nachweisen, dass ein Zusammenhang zwischen FABP5 und TGF- $\beta$ besteht. TGF- $\beta$, ein multifunktionelles Zytokin, moduliert in Neuronen des Mittelhirns die Proteasomenfunktion, und es konnte eine starke Erhöhung von FABP5 nach TGF- $\beta$-Gabe beobachtet werden. Somit scheint TGF- $\beta$ über die Bildung von Proteinen wie FABP5 die Neuronenregeneration zu beeinflussen. Blaney Davidson et al. (2005) zeigten in einem Mausmodell, dass in alten Mäusen, die einer hohen Gelenkbelastung ausgesetzt waren, TGF- $\beta$ und dessen Rezeptor stark vermindert waren. In einem anderen Tiermodell konnte an Schweinen gezeigt werden, dass eine TGF- $\beta$-Injektion in das erkrankte Kniegelenk zu einer Regeneration von degenerierten Knorpeldefekten führt (Hunziker 2001). Diese Studien zeigen, dass TGF- $\beta$ eine entscheidende Rolle bei der Entstehung der OA spielen. Außerdem stehen TGF- $\beta$ und FABP5 in einem Zusammenhang, der allerdings für die OA und speziell für CPCs bis jetzt noch nicht untersucht worden ist. 


\subsection{Fazit und Ausblick}

Durch den Knockdown von FABP5 in den CPCs wurde die Expression des osteogenen Transkriptionsfaktors RUNX2 beeinflusst. Die unterschiedlichen Rollen, die FABP5 in verschiedenen Zellpopulationen, wie z.B. bei Entzündungsreaktionen sowie in Funktion als Adipokin spielt, geben FABP5 eine weitaus größere Bedeutung als nur die des einfachen Transportproteins. Die gezeigten Versuche wurden in 2DZellkulturen durchgeführt und nicht in 3D-Zellkulturen, in denen CPCs eine größere Syntheseaktivität zeigen. Die Syntheseaktivität spezifischer Proteine, die im gesunden hyalinen Knorpel vorkommen wie Kollagene und Proteoglykane in den transfizierten CPCs ist deshalb vor allem in 3D-Zellkulturen zu untersuchen. Weiterhin muss die Art der Interaktion von FABP5 und RUNX2 untersucht werden. Hierzu könnte mithilfe von Copräzipitationen, Pulldown-Assays und weiteren Methoden die Frage geklärt werden, ob FABP5 direkt mit RUNX2 interagiert oder ob noch andere Proteine und Liganden von FABP5 die Expression von RUNX2 beeinflussen. 


\section{Zusammenfassung}

OA ist eine degenerative Gelenkerkrankung, bei der vor allem der Gelenkknorpel und die umliegenden Gewebe zerstört werden. Die Symptome dieses Gelenkverschleißes reichen von Schmerzen bis hin zu komplettem Mobilitätsverlust. Die bisherigen Therapieansätze zielen darauf ab, die Schmerzen zu lindern und die Bewegungsfähigkeit zu verbessern oder wieder herzustellen. Bei den Regenerationsprozessen wird minderwertiges fibrokartilaginäres Ersatzgewebe anstelle von hyalinem Knorpel gebildet. In dem fibrokartilaginären Ersatzgewebe befinden sich jedoch chondrogene Progenitorzellen (CPCs). Sie könnten potenzielles Ziel medikamentöser Therapien sein, um das Regenerationspotenzial dieser Zellen zu stimulieren.

In der vorliegenden Arbeit konnte erstmals FABP5, ein Interaktionspartner des Transkriptionsfaktors RUNX2, in den CPCs nachgewiesen werden. Dieser Nachweis erfolgte auf zellulärer und Gewebeebene sowie auf mRNA- und Proteinebene. Es konnte gezeigt werden, dass der Knockdown von FABP5 die Expression von RUNX2 und Kollagen-Typ 1 beeinflusst. Beide Proteine wurden nach dem Knockdown vermindert exprimiert. Auf die Expression von SOX9, den Antagonisten von RUNX2, hatte der FABP5-Knockdown keine Auswirkungen. So kann davon ausgegangen werden, dass FABP5 auf die durch RUNX2 gesteuerte osteogene Differenzierung der CPCs Einfluss nimmt.

Diese Ergebnisse zeigen, dass FABP5 mit RUNX2 interagiert und die Differenzierung der CPCs beeinflusst. Ob FABP5 auf RUNX2 direkt, über die Liganden von FABP5 (Fettsäuren) oder dazwischengeschaltete Proteine einwirkt, muss in weiteren Studien untersucht werden. Des Weiteren muss geklärt werden, ob der Knockdown von FABP5 in den CPCs deren chondrogene Differenzierung antreibt und letztendlich gesünderer hyaliner Knorpel gebildet werden kann. 


\section{Anhang}

\subsection{Abbildungsverzeichnis}

Abbildung 1: Die molekulare Organisation des gesunden Knorpels ......................... 3

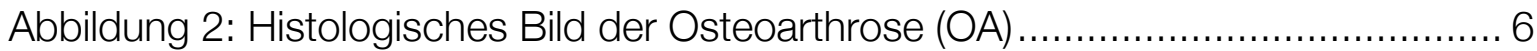

Abbildung 3: Das Konzept der Progenitorzellen in situ ................................. 9

Abbildung 4: Kristallstruktur des humanen FABP5 mit einer gebundenen

Fettsäure.

Abbildung 5: Immunhistochemischer Nachweis von FABP5 in erkranktem Knorpel.

Abbildung 6: Zellkultur chondrogener Progenitorzellen nach der Transfektion mit GFP

Abbildung 7: Western Blot-Ergebnisse für FABP5 und a-Tubulin 39

Abbildung 8: Quantitative Auswertung des relativen mRNA-Levels und des

Proteinlevels von FABP5 in CPCs vor und nach dem Knockdown von

FABP5.

Abbildung 9: Quantitative Auswertung des relativen mRNA-Levels und des

Proteinlevels von SOX9 in CPCs vor und nach dem Knockdown von FABP5

Abbildung 10: Quantitative Auswertung des relativen mRNA-Levels und des

Proteinlevels von RUNX2 in CPCs vor und nach dem Knockdown von FABP5

Abbildung 11: Quantitative Auswertung des relativen mRNA-Levels und des

Proteinlevels von Kollagen-Typ 1 in CPCs vor und nach dem Knockdown von FABP5 


\subsection{Tabellenverzeichnis}

Tabelle 1: Protokoll Immunhistochemie................................................. 18

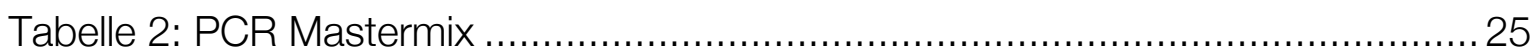

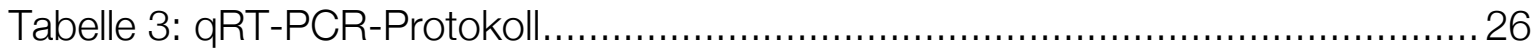

Tabelle 4: Gradienten-PCR: Pipettierschema ........................................... 27

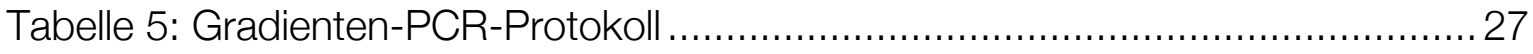

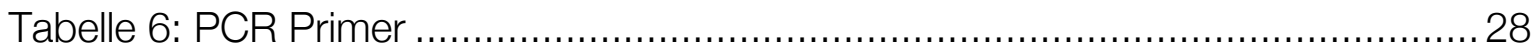

Tabelle 7: Zusammensetzung Trenngel (10 \%) ........................................... 31

Tabelle 8: Zusammensetzung Sammelgel..................................................... 32

Tabelle 9: Western Blot: Verwendete Primärantikörper ..................................... 35

Tabelle 10: Western Blot: Verwendete Sekundärantikörper................................ 35 


\section{Literaturverzeichnis}

Adida A, Spener F (2006): Adipocyte-type fatty acid-binding protein as intercompartmental shuttle for peroxisome proliferator activated receptor gamma agonists in cultured cell. Biochim Biophys Acta 1761, 172-181

Afif H, Benderdour M, Mfuna-Endam L, Martel-Pelletier J, Pelletier JP, Duval N, Fahmi H (2007): Peroxisome proliferator-activated receptor gamma1 expression is diminished in human osteoarthritic cartilage and is downregulated by interleukin1 beta in articular chondrocytes. Arthritis Res Ther $\underline{9}$, R31

Akiyama H, Chaboissier MC, Martin JF, Schedl A, de Crombrugghe B (2002): The transcription factor sox 9 has essential roles in successive steps of the chondrocyte differentiation pathway and is required for expression of sox5 and sox6. Genes Dev $\underline{16}, 2813-2828$

Akiyama H, Kim JE, Nakashima K, Balmes G, Iwai N, Deng JM, Zhang Z, Martin JF, Behringer RR, Nakamura T et al. (2005): Osteo-chondroprogenitor cells are derived from sox9 expressing precursors. Proc Natl Acad Sci U S A 102, 14665-14670

Bando Y, Yamamoto M, Sakiyama K, Inoue K, Takizawa S, Owada Y, Iseki S, Kondo $\mathrm{H}$, Amano $\mathrm{O}$ (2014): Expression of epidermal fatty acid binding protein (e-fabp) in septoclasts in the growth plate cartilage of mice. J Mol Histol $\underline{45}, 507-518$

Blagojevic M, Jinks C, Jeffery A, Jordan KP (2010): Risk factors for onset of osteoarthritis of the knee in older adults: A systematic review and meta-analysis. Osteoarthritis Cartilage $\underline{18}, 24-33$

Blaney Davidson EN, Scharstuhl A, Vitters EL, van der Kraan PM, van den Berg WB (2005): Reduced transforming growth factor-beta signaling in cartilage of old mice: Role in impaired repair capacity. Arthritis Res Ther $\underline{7}$, R1338-1347 
Blaney Davidson EN, van der Kraan PM, van den Berg WB (2007): Tgf-beta and osteoarthritis. Osteoarthritis Cartilage 15, 597-604

Boileau C, Martel-Pelletier J, Fahmi H, Mineau F, Boily M, Pelletier JP (2007): The peroxisome proliferator-activated receptor gamma agonist pioglitazone reduces the development of cartilage lesions in an experimental dog model of osteoarthritis: In vivo protective effects mediated through the inhibition of key signaling and catabolic pathways. Arthritis Rheum 트, 2288-2298

Bruckner P, van der Rest M (1994): Structure and function of cartilage collagens. Microsc Res Tech 28, 378-384

Canas JA, Damaso L, Hossain J, Balagopal PB (2015): Fatty acid binding proteins 4 and 5 in overweight prepubertal boys: Effect of nutritional counselling and supplementation with an encapsulated fruit and vegetable juice concentrate. J Nutr Sci $\underline{4}$, e39

Carames B, Taniguchi N, Otsuki S, Blanco FJ, Lotz M (2010): Autophagy is a protective mechanism in normal cartilage, and its aging-related loss is linked with cell death and osteoarthritis. Arthritis Rheum 62, 791-801

Challa TD, Rais Y, Ornan EM (2010): Effect of adiponectin on atdc5 proliferation, differentiation and signaling pathways. Mol Cell Endocrinol $\underline{323}$, 282-291

Cheng A, Genever PG (2010): Sox9 determines runx2 transactivity by directing intracellular degradation. J Bone Miner Res 25, 2680-2689

Chmurzynska A (2006): The multigene family of fatty acid-binding proteins (fabps): Function, structure and polymorphism. J Appl Genet 47, 39-48 
Chu ML, Pan TC, Conway D, Saitta B, Stokes D, Kuo HJ, Glanville RW, Timpl R, Mann K, Deutzmann R (1990): The structure of type vi collagen. Ann N Y Acad Sci $\underline{580}, 55-63$

Cingöz G: Identifizierung neuer coregulatoren von sox9 und runx2 in chondrogenen progenitorzellen in der osteoarthrose. Mathemathisch-naturwissenschaftliche Dissertation Göttingen 2015

Considine RV, Sinha MK, Heiman ML, Kriauciunas A, Stephens TW, Nyce MR, Ohannesian JP, Marco CC, McKee LJ, Bauer TL, et al. (1996): Serum immunoreactive-leptin concentrations in normal-weight and obese humans. N Engl J Med 334, 292-295

Cucchiarini M, Thurn T, Weimer A, Kohn D, Terwilliger EF, Madry H (2007): Restoration of the extracellular matrix in human osteoarthritic articular cartilage by overexpression of the transcription factor sox9. Arthritis Rheum $\underline{56}, 158-167$

Cucchiarini M, Madry H, Guilak F, Saris DB, Stoddart MJ, Koon Wong M, Roughley P (2014): A vision on the future of articular cartilage repair. Eur Cell Mater 27, 12-16

de Boer TN, van Spil WE, Huisman AM, Polak AA, Bijlsma JW, Lafeber FP, Mastbergen SC (2012): Serum adipokines in osteoarthritis; comparison with controls and relationship with local parameters of synovial inflammation and cartilage damage. Osteoarthritis Cartilage 20, 846-853

Ducy P, Zhang R, Geoffroy V, Ridall AL, Karsenty G (1997): Osf2/cbfa1: A transcriptional activator of osteoblast differentiation. Cell 89, 747-754

Duplus E, Glorian M, Forest C (2000): Fatty acid regulation of gene transcription. J Biol Chem 275, 30749-30752 
Ehling A, Schaffler A, Herfarth H, Tarner $\amalg$, Anders S, Distler O, Paul G, Distler J, Gay S, Scholmerich J, et al. (2006): The potential of adiponectin in driving arthritis. J Immunol 176, 4468-4478

Eyre D (2002): Collagen of articular cartilage. Arthritis Res $\underline{4}$, 30-35

Felson DT (2006): Clinical practice. Osteoarthritis of the knee. N Engl J Med 354 , 841-848

Fisher LW, Termine JD, Young MF (1989): Deduced protein sequence of bone small proteoglycan i (biglycan) shows homology with proteoglycan ii (decorin) and several nonconnective tissue proteins in a variety of species. J Biol Chem 264, 4571-4576

Furuhashi M, Ishimura S, Ota H, Miura T (2011): Lipid chaperones and metabolic inflammation. Int J Inflam 2011, 642612

Gannon JM, Walker G, Fischer M, Carpenter R, Thompson RC, Jr., Oegema TR, Jr. (1991): Localization of type $x$ collagen in canine growth plate and adult canine articular cartilage. J Orthop Res $\underline{9}$, 485-494

Goldring MB, Goldring SR (2007): Osteoarthritis. J Cell Physiol 213, 626-634

Goldring MB, Marcu KB (2009): Cartilage homeostasis in health and rheumatic diseases. Arthritis Res Ther 11, 224

Goldring MB, Goldring SR (2010): Articular cartilage and subchondral bone in the pathogenesis of osteoarthritis. Ann N Y Acad Sci 1192, 230-237

Goldring MB, Tsuchimochi K, ljiri K (2006): The control of chondrogenesis. J Cell Biochem 97, 33-44 
Guilak F, Fermor B, Keefe FJ, Kraus VB, Olson SA, Pisetsky DS, Setton LA, Weinberg JB (2004): The role of biomechanics and inflammation in cartilage injury and repair. Clin Orthop Relat Res, 17-26

Heinegard D, Saxne T (2011): The role of the cartilage matrix in osteoarthritis. Nat Rev Rheumatol 7, 50-56

Hihi AK, Michalik L, Wahli W (2002): Ppars: Transcriptional effectors of fatty acids and their derivatives. Cell Mol Life Sci $\underline{59}, 790-798$

Hohoff C, Borchers T, Rustow B, Spener F, van Tilbeurgh H (1999): Expression, purification, and crystal structure determination of recombinant human epidermaltype fatty acid binding protein. Biochemistry 38, 12229-12239

Hotamisligil GS, Johnson RS, Distel RJ, Ellis R, Papaioannou VE, Spiegelman BM (1996): Uncoupling of obesity from insulin resistance through a targeted mutation in ap2, the adipocyte fatty acid binding protein. Science $\underline{274}$, 1377-1379

Huber M, Trattnig S, Lintner F (2000): Anatomy, biochemistry, and physiology of articular cartilage. Invest Radiol 35, 573-580

Hunziker EB (2001): Growth-factor-induced healing of partial-thickness defects in adult articular cartilage. Osteoarthritis Cartilage $\underline{9}$, 22-32

Johnson LL (1986): Arthroscopic abrasion arthroplasty historical and pathologic perspective: Present status. Arthroscopy 2, 54-69

Johannsen I: Die entzündungsmodulierenden Eigenschaften von Adiponectin und Leptin und deren Wirkung auf chondrogene Progenitorzellen. Med. Diss. Göttingen 2016 
Jonason JH, Xiao G, Zhang M, Xing L, Chen D (2009): Post-translational regulation of runx2 in bone and cartilage. J Dent Res $\underline{88}$, 693-703

Kaess BM, Enserro DM, McManus DD, Xanthakis V, Chen MH, Sullivan LM, Ingram C, O'Donnell CJ, Keaney JF, Vasan RS et al. (2012): Cardiometabolic correlates and heritability of fetuin-a, retinol-binding protein 4 , and fatty-acid binding protein 4 in the framingham heart study. J Clin Endocrinol Metab 푸, E1943-1947

Kapoor M, Kojima F, Qian M, Yang L, Crofford LJ (2007): Microsomal prostaglandin e synthase-1 deficiency is associated with elevated peroxisome proliferator-activated receptor gamma: Regulation by prostaglandin e2 via the phosphatidylinositol 3kinase and akt pathway. J Biol Chem 282, 5356-5366

Kiefer JC (2007): Back to basics: Sox genes. Dev Dyn 236, 2356-2366

Knoferle J, Ramljak S, Koch JC, Tonges L, Asif AR, Michel U, Wouters FS, Heermann S, Krieglstein K, Zerr I, et al. (2010): Tgf-beta 1 enhances neurite outgrowth via regulation of proteasome function and efabp. Neurobiol Dis $\underline{38}, 395-$ 404

Kobayashi T, Notoya K, Naito T, Unno S, Nakamura A, Martel-Pelletier J, Pelletier JP (2005): Pioglitazone, a peroxisome proliferator-activated receptor gamma agonist, reduces the progression of experimental osteoarthritis in guinea pigs. Arthritis Rheum 52, 479-487

Koelling S, Kruegel J, Irmer M, Path JR, Sadowski B, Miro X, Miosge N (2009): Migratory chondrogenic progenitor cells from repair tissue during the later stages of human osteoarthritis. Cell Stem Cell $\underline{4}$, 324-335

Kralisch S, Fasshauer M (2013): Adipocyte fatty acid binding protein: A novel adipokine involved in the pathogenesis of metabolic and vascular disease? Diabetologia $\underline{56}, 10-21$ 
Kreuz PC, Steinwachs MR, Erggelet C, Krause SJ, Konrad G, Uhl M, Sudkamp N (2006): Results after microfracture of full-thickness chondral defects in different compartments in the knee. Osteoarthritis Cartilage 14, 1119-1125

Kuettner KE (1992): Biochemistry of articular cartilage in health and disease. Clin Biochem 25, 155-163

Lefebvre V, Smits P (2005): Transcriptional control of chondrocyte fate and differentiation. Birth Defects Res C Embryo Today $\underline{75}$, 200-212

Lefebvre V, Huang W, Harley VR, Goodfellow PN, de Crombrugghe B (1997): Sox9 is a potent activator of the chondrocyte-specific enhancer of the pro alpha1(ii) collagen gene. Mol Cell Biol 17, 2336-2346

Liu R-Z, Mita R, Beaulieu M, Gao Z, Godbout R (2010): Fatty acid binding proteins in brain development and disease. Int J Dev Biol 느, 1229-1239

Loeser RF, Goldring SR, Scanzello CR, Goldring MB (2012): Osteoarthritis: A disease of the joint as an organ. Arthritis Rheum $\underline{64}, 1697-1707$

Lohmander LS, Roos EM (2007): Clinical update: Treating osteoarthritis. Lancet $\underline{370}$, 2082-2084

Long F (2012): Building strong bones: Molecular regulation of the osteoblast lineage. Nat Rev Mol Cell Biol 13, 27-38

Lubbeke A, Finckh A, Puskas GJ, Suva D, Ladermann A, Bas S, Fritschy D, Gabay C, Hoffmeyer P (2013): Do synovial leptin levels correlate with pain in end stage arthritis? Int Orthop 37, 2071-2079 
Madsen P, Rasmussen HH, Leffers H, Honore B, Celis JE (1992): Molecular cloning and expression of a novel keratinocyte protein (psoriasis-associated fatty acidbinding protein [pa-fabp]) that is highly up-regulated in psoriatic skin and that shares similarity to fatty acid-binding proteins. J Invest Dermatol 99, 299-305

Mankin HJ, Buckwalter JA (1996): Restoration of the osteoarthrotic joint. J Bone Joint Surg Am $\underline{78}, 1-2$

Mayne R (1989): Cartilage collagens. What is their function, and are they involved in articular disease? Arthritis Rheum $\underline{32}, 241-246$

Miosge N, Hartmann M, Maelicke C, Herken R (2004): Expression of collagen type I and type II in consecutive stages of human osteoarthritis. Histochem Cell Biol $\underline{122}$, 229-236

Morgelin M, Paulsson M, Heinegard D, Aebi U, Engel J (1995): Evidence of a defined spatial arrangement of hyaluronate in the central filament of cartilage proteoglycan aggregates. Biochem J 307 ( Pt 2), 595-601

Muhammad H, Schminke B, Miosge N (2013): Current concepts in stem cell therapy for articular cartilage repair. Expert Opin Biol Ther 13, 541-548

Muller S, Breederveld RS, Tuinebreijer WE (2010): Results of osteochondral autologous transplantation in the knee. Open Orthop J $\underline{4}, 111-114$

Mundlos S, Otto F, Mundlos C, Mulliken JB, Aylsworth AS, Albright S, Lindhout D, Cole WG, Henn W, Knoll JH, et al. (1997): Mutations involving the transcription factor cbfa1 cause cleidocranial dysplasia. Cell $\underline{89}$, 773-779

Murphy G, Nagase H (2008): Reappraising metalloproteinases in rheumatoid arthritis and osteoarthritis: Destruction or repair? Nat Clin Pract Rheumatol $\underline{4}, 128-135$ 
Murphy L, Schwartz TA, Helmick CG, Renner JB, Tudor G, Koch G, Dragomir A, Kalsbeek WD, Luta G, Jordan JM (2008): Lifetime risk of symptomatic knee osteoarthritis. Arthritis Rheum $\underline{59}, 1207-1213$

Ohira H, Fujioka Y, Katagiri C, Mamoto R, Aoyama-Ishikawa M, Amako K, Izumi Y, Nishiumi S, Yoshida M, Usami M et al. (2013): Butyrate attenuates inflammation and lipolysis generated by the interaction of adipocytes and macrophages. J Atheroscler Thromb 20, 425-442

Oldberg A, Antonsson P, Lindblom K, Heinegard D (1989): A collagen-binding 59-kd protein (fibromodulin) is structurally related to the small interstitial proteoglycans pgs1 and pg-s2 (decorin). Embo j $\underline{8}, 2601-2604$

Oliveria SA, Felson DT, Cirillo PA, Reed JI, Walker AM (1999): Body weight, body mass index, and incident symptomatic osteoarthritis of the hand, hip, and knee. Epidemiology 10, 161-166

Otto F, Thornell AP, Crompton T, Denzel A, Gilmour KC, Rosewell IR, Stamp GW, Beddington RS, Mundlos S, Olsen BR, et al. (1997): Cbfa1, a candidate gene for cleidocranial dysplasia syndrome, is essential for osteoblast differentiation and bone development. Cell $\underline{89}$, 765-771

Pfaffl MW (2001): A new mathematical model for relative quantification in real-time rtpcr. Nucleic Acids Res 29, e45

Pfaffl MW, Horgan GW, Dempfle L (2002): Relative expression software tool (rest) for group-wise comparison and statistical analysis of relative expression results in realtime pcr. Nucleic Acids Res $\underline{30}$, e36

Poole AR, Pidoux I (1989): Immunoelectron microscopic studies of type x collagen in endochondral ossification. J Cell Biol 109, 2547-2554 
Poole CA (1997): Articular cartilage chondrons: Form, function and failure. J Anat 191 ( Pt 1), 1-13

Poonpet T, Honsawek S (2014): Adipokines: Biomarkers for osteoarthritis? World J Orthop $\underline{5}, 319-327$

Robert Koch-Institut (Hrsg.): Arthrose. Gesundheitsberichterstattung des Bundes. Heft 54. RKI, Berlin 2013

Robert Koch-Institut (Hrsg.): Daten und Fakten: Ergebnisse der Studie "Gesundheit in Deutschland aktuell 2012". Beiträge zur Gesundheitsberichterstattung des Bundes. RKI, Berlin 2014

Schminke B, Miosge N (2014): Cartilage repair in vivo: The role of migratory progenitor cells. Curr Rheumatol Rep 16, 461

Shaughnessy S, Smith ER, Kodukula S, Storch J, Fried SK (2000): Adipocyte metabolism in adipocyte fatty acid binding protein knockout mice (ap2-/-) after shortterm high-fat feeding: Functional compensation by the keratinocyte [correction of keritinocyte] fatty acid binding protein. Diabetes $\underline{49}$, 904-911

Shibue K, Yamane S, Harada N, Hamasaki A, Suzuki K, Joo E, Iwasaki K, Nasteska D, Harada T, Hayashi $Y$, et al. (2015): Fatty acid-binding protein 5 regulates dietinduced obesity via gip secretion from enteroendocrine $k$ cells in response to fat ingestion. Am J Physiol Endocrinol Metab $\underline{308}$, E583-591

Smathers RL, Petersen DR (2011): The human fatty acid-binding protein family: Evolutionary divergences and functions. Hum Genomics $\underline{5}, 170-191$

Sock E, Pagon RA, Keymolen K, Lissens W, Wegner M, Scherer G (2003): Loss of DNA-dependent dimerization of the transcription factor sox 9 as a cause for campomelic dysplasia. Hum Mol Genet 12, 1439-1447 
Steadman JR, Briggs KK, Rodrigo JJ, Kocher MS, Gill TJ, Rodkey WG (2003): Outcomes of microfracture for traumatic chondral defects of the knee: Average 11year follow-up. Arthroscopy 19, 477-484

Storch J, McDermott L (2009): Structural and functional analysis of fatty acid-binding proteins. J Lipid Res 50 Suppl, S126-131

Storch J, Thumser AE (2010): Tissue-specific functions in the fatty acid-binding protein family. J Biol Chem 285, 32679-32683

Tan NS, Shaw NS, Vinckenbosch N, Liu P, Yasmin R, Desvergne B, Wahli W, Noy N (2002): Selective cooperation between fatty acid binding proteins and peroxisome proliferator-activated receptors in regulating transcription. Mol Cell Biol 22, 51145127

Tesche F, Miosge N (2005): New aspects of the pathogenesis of osteoarthritis: The role of fibroblast-like chondrocytes in late stages of the disease. Histol Histopathol 20, 329-337

Thijssen E, van Caam A, van der Kraan PM (2015): Obesity and osteoarthritis, more than just wear and tear: Pivotal roles for inflamed adipose tissue and dyslipidaemia in obesity-induced osteoarthritis. Rheumatology (Oxford) $\underline{54,588-600}$

Thumser AE, Moore JB, Plant NJ (2014): Fatty acid binding proteins: Tissue-specific functions in health and disease. Curr Opin Clin Nutr Metab Care 17, 124-129

Ushiyama T, Chano T, Inoue $\mathrm{K}$, Matsusue $\mathrm{Y}$ (2003): Cytokine production in the infrapatellar fat pad: Another source of cytokines in knee synovial fluids. Ann Rheum Dis $\underline{62}, 108-112$

van der Rest M, Mayne R (1988): Type ix collagen proteoglycan from cartilage is covalently cross-linked to type ii collagen. J Biol Chem 263, 1615-1618 
Vasheghani F, Zhang Y, Li YH, Blati M, Fahmi H, Lussier B, Roughley P, Lagares D, Endisha H, Saffar B et al. (2015): Ppargamma deficiency results in severe, accelerated osteoarthritis associated with aberrant mtor signalling in the articular cartilage. Ann Rheum Dis $\underline{74}, 569-578$

Vos T, Flaxman AD, Naghavi M, Lozano R, Michaud C, Ezzati M, Shibuya K, Salomon JA, Abdalla S, Aboyans $V$ et al. (2012): Years lived with disability (ylds) for 1160 sequelae of 289 diseases and injuries 1990-2010: A systematic analysis for the global burden of disease study 2010. Lancet 380, 2163-2196

Wagner T, Wirth J, Meyer J, Zabel B, Held M, Zimmer J, Pasantes J, Bricarelli FD, Keutel J, Hustert E et al. (1994): Autosomal sex reversal and campomelic dysplasia are caused by mutations in and around the sry-related gene sox9. Cell $\underline{79}, 1111$ 1120

Wang X, Manner PA, Horner A, Shum L, Tuan RS, Nuckolls GH (2004): Regulation of mmp-13 expression by runx2 and fgf2 in osteoarthritic cartilage. Osteoarthritis Cartilage $\underline{12}, 963-973$

Wegner M (1999): From head to toes: The multiple facets of sox proteins. Nucleic Acids Res 27, 1409-1420

Wieland HA, Michaelis M, Kirschbaum BJ, Rudolphi KA (2005): Osteoarthritis - an untreatable disease? Nat Rev Drug Discov $\underline{4}$, 331-344

Wu JJ, Woods PE, Eyre DR (1992): Identification of cross-linking sites in bovine cartilage type ix collagen reveals an antiparallel type ii-type ix molecular relationship and type ix to type ix bonding. J Biol Chem 267, 23007-23014

Wuelling M, Vortkamp A (2010): Transcriptional networks controlling chondrocyte proliferation and differentiation during endochondral ossification. Pediatr Nephrol 25, 625-631 
Yamasaki S, Nakashima T, Kawakami A, Miyashita T, Tanaka F, Ida H, Migita K, Origuchi T, Eguchi K (2004): Cytokines regulate fibroblast-like synovial cell differentiation to adipocyte-like cells. Rheumatology (Oxford) 43, 448-452

Zhang Y, Jordan JM (2010): Epidemiology of osteoarthritis. Clin Geriatr Med 26, 355369

Zhang Y, Yang JH (2013): Activation of the pi3k/akt pathway by oxidative stress mediates high glucose-induced increase of adipogenic differentiation in primary rat osteoblasts. J Cell Biochem 114, 2595-2602 


\section{Danksagung}

Mein besonderer Dank gilt Herrn Prof. Dr. med. Nicolai Miosge für die geduldige und außergewöhnlich gute Betreuung und Unterstützung bei der Entstehung dieser Arbeit. Danken möchte ich auch für die Möglichkeit, einen Einblick in das wissenschaftliche Arbeiten in einem Labor zu erhalten.

Ich danke Frau Andrea Bernhard und Frau Christa Bode, dass sie mir während der gesamten Zeit mit ihrer kompetenten Hilfe und ihrem kostbaren Rat zur Seite standen.

Ich bedanke mich bei der gesamten Arbeitsgruppe, ganz besonders bei Elke Henze und meinen Mitstreiterinnen und Mitstreitern Evi Tsiakourma, Katharina Kroeber, Theresa Blume, Manuel Altherr, Thomas Gelis und Tobias Vollmer für die vielen schönen Stunden im Labor und das tolle Arbeitsklima.

Bei Dr. med. dent. Andrea Schubert, Dr. med. dent. Robert Eschholz und Rebecca Buderer bedanke ich mich für die Korrekturlesungen und Anregungen. 